\title{
Fenomenologia ucieleśniona (embodied phenomenology) a teza o tożsamości psychofizycznej
}

\author{
Tomasz Kąkol \\ (Uniwersytet Gdański, Instytut Filozofii)
}

[...] how a brain (or anything else that is physical) could manage to be a locus of conscious experience... This is, surely, among the ultimate metaphysical mysteries; don't bet on anybody ever solving it.

J.A. Fodor

[...] we will not get very far in giving a scientific account of the relationship between consciousness and the brain unless we have a clear conception of what it is that we are trying to relate.

S. Gallagher, D. Zahavi

\section{Wstęp}

W XX- i XXI-wiecznej filozofii umysłu wiele analiz poświęcono argumentacji za tezą o tożsamości psychofizycznej i przeciw niej. Jeśliby jednak zapytać kogoś, kto studiował ten problem pod kierunkiem np. Saula Kripkego, Jaegwona Kima czy Davida Chalmersa, jak zapatruje się na tę kwestię fenomenologia, odpowiedziałby zapewne, że albo nie interesuje jej to zagadnienie, albo (co bardziej prawdopodobne) odrzeknie, że bliżej (co najmniej) jej do negacji tej tezy, gdyż fenomenologia od początku stanowiła nurt antynaturalistyczny w filozofii. Funkcjonuje 
jednak dość liczna grupa badaczy nie ograniczających się do egzegezy dzieł Edmunda Husserla i jego uczniów czy kontynuatorów, ale rozumiejących znaczenie ich wglądów dla współczesnej kognitywistyki, z którą to kognitywistyką współpracują, a nie tylko krytykują. Nurt ten najprościej określić mianem „fenomenologii ucieleśnionej”, gdyż fenomen ucieleśnienia (embodiment), różnie zresztą opisywany przez takich myślicieli jak Edmund Husserl, Maurice Merleau-Ponty, Jean-Paul Sartre czy Paul Ricoeur, jest przez nich uważany za kluczowy dla zrozumienia wielu problemów filozoficznych. Sądzę, że badaczy pracujących w ramach analitycznej filozofii umysłu - zarówno zwolenników, jak i przeciwników tezy o tożsamości psychofizycznej - może zaciekawić fakt, że rzeczona teza zdaje się otrzymywać nieoczekiwane (w świetle stereotypowego rozumienia fenomenologii) poparcie właśnie ze strony nurtu kojarzonego z najwybitniejszym antynaturalistą początku XX wieku: Husserlem. W artykule tym będę jednak bronił tezy, że jest to pozór: kwestia tożsamości psychofizycznej pozostaje otwarta.

Fragmenty prawie 700-stronicowej pracy zbiorowej pod redakcją lidera tego nurtu, Shauna Gallaghera (oraz Daniela Schmickinga)1, zdają się nie pozostawiać wątpliwości: Dorothée Legrand pyta retorycznie: „czy można być samoświadomym bez bycia ciałem?"2; niżej czytamy, "jak to jest być ciałem” (what it feels like to be a body) ${ }^{3}$, a nieco dalej, iż „postrzegające ja (self) odpowiada ciału-jako-podmiotowi”, lecz „ciało-jako-podmiot jest tym samym obiektem fizycznym, co ciało-jako-przedmiot”4. Podobnie pisze kolejny autor, Jean-Luc Petit, o „doświadczeniu (experience) bycia ciałem" ${ }^{\prime \prime}$, natomiast David Morris pisze bez ogródek, że „umysł jest ciałem... ciało jest umysłem” (podkr. w oryg.) ${ }^{6}$. W swojej innej pracy Gallagher wraz z Danem Zahavim, innym wybitnym przedstawicielem współ-

1 Handbook of Phenomenology and Cognitive Science, eds. S. Gallagher, D. Schmicking, Springer, Dordrecht-New York-Heidelberg-London 2010. Przekłady z angielskiego, o ile nie zaznaczono inaczej - T.K.

2 D. Legrand, Myself with No Body? Body, Bodily-Consciousness and Self-consciousness, w: Handbook of Phenomenology and Cognitive Science, dz. cyt., s. 181 i nn.

3 Tamże, s. 183.

4 Tamże, s. 188.

5 J.-L. Petit, A Husserlian, Neurophenomenological Approach to Embodiment, w: Handbook of Phenomenology and Cognitive Science, dz. cyt., s. 203.

6 D. Morris, Empirical and Phenomenological Studies of Embodied Cognition, w: Handbook of Phenomenology and Cognitive Science, dz. cyt., s. 242. 
czesnej fenomenologii, piszą o „ciału jako podmiocie, jako doświadczającym, jako sprawcy"7 - tj., że ,jestem nim” (I am it), tj. owym ciałem ${ }^{8}$ - a żeby nie było wątpliwości, dodają: „co opisujemy jako przeżywane (lived) ciało z perspektywy fenomenologicznej, jest dokładnie tym samym ciałem, co ciało biologiczne, które badamy z perspektywy obiektywnej”. Pytanie Kartezjusza (i nie tylko) „kim jestem?” zyskuje zatem jasną, niekartezjańską odpowiedź: jestem (pewnym) ciałem. Jak brzmi jednak argument za tą tezą? Czy może raczej - skoro mowa o fenomenologii - jest to po prostu teza opisowa, zdająca sprawę z pewnego faktu?

Spróbujmy wpierw pójść drogą z pozoru odległą od fenomenologii - tj. pytając o odniesienie wyrażeń nominalnych w tezie „[ja] jestem [pewnym] ciałem” ${ }^{10}$.

\section{Nieredukowalność ja}

Do czego odnosi się „ja”? Na pierwszy rzut oka sprawa wydaje się jasna: do czegokolwiek, co wypowiedziało zdanie (czy koniecznie całe zdanie?) zawierające „ja" ${ }^{\prime 1}$. A jeśli jest to papuga, komputer lub choćby człowiek nie znający tej rzekomej reguły semantycznej ${ }^{12}$ ? W tym ostatnim przypadku nie ma, jak się zdaje, problemu: wystarczy odróżnić odniesienie wyrażenia i odniesienie użytkowni$k a^{13}$ - to pierwsze określa reguła podana wyżej, to drugie zaś może nawet nie istnieć (lub rozmijać się z pierwszym). Tylko że takowe reguły określa właśnie użytkownik lub (jak choćby w przypadku „ja”) jacyś przeszli użytkownicy, zatem możemy ich rozważyć. Oto i oni - możemy założyć, że „wynaleźli” właśnie

7 S. Gallagher, D. Zahavi, The Phenomenological Mind. An Introduction to Philosophy of Mind and Cognitive Science, Routledge, London-New York 2008, s. 136.

8 Tamże, s. 143.

9 Tamże, s. 140.

10 Zamiast tłumaczyć się z rozumienia relacji między filozofią analityczną a fenomenologią, odpowiem słowami Davida Woodruffa Smitha: „Może i jest przepaść kulturowa między tymi tradycjami, ale nie ma między nimi przepaści filozoficznej, jeśli chodzi o zagadnienia, które tu poruszę" (D.W. Smith, The Circle of Acquaintance. Perception, Consciousness, and Empathy, Kluwer, Dordrecht-Boston-London 1989, s. 2).

11 Por. np. J. Campbell, Personal Identity, w: The Oxford Handbook of The Self, ed. S. Gallagher, Oxford University Press, New York 2011, s. 344.

12 Por. np. J. Bremer, Osoba - fikcja czy rzeczywistość? Tożsamość i jedność Ja w świetle badań neurologicznych, Aureus, Kraków 2008, s. 261.

13 Por. S.A. Kripke, Nazywanie a konieczność, tł. B. Chwedeńczuk, PAX, Warszawa 1988, s. 28 i nn., zwł. przyp. 3. 
reguły semantyczne rządzące słowami np. „tu”, „teraz”, „ty” i „on”, a teraz kolej na „ja”. Czy rozumują tak: „niech «ja» odnosi się do czegokolwiek, co wypowiada zdanie lub inne wyrażenie zawierające «ja». Oto jaskiniowiec z naprzeciwka jęknął coś w rodzaju «ja». Gdyby więc miał to na myśli, co ja [sic!] teraz, odniósłby się - zgodnie z regułą wyżej - do siebie. O - właśnie użyłem «ja». A zatem, odniosłem się do siebie". Ta zmyślona historyjka - zmyślona w tym samym sensie, co nowożytne opowieści o zawarciu dawno temu tzw. umowy społecznej - ma jednak w sobie (podobne jak owe opowieści) ziarno prawdy: pokazuje, że znajomość reguły określającej odniesienie „ja” zakłada zdolność do autoreferencji (odnoszenia się do siebie) ${ }^{14}$. Inny wariant tej historyjki mógłby być taki: „niech «ja» odnosi się do czegokolwiek, co wypowiada zdanie lub inne wyrażenie zawierające «ja». Ja mam... A zatem, ja [sic!] odniosłem się do siebie".

Ktoś powie: „ależ nie, rozważ taką wypowiedź: «Siedzący Byk jest zły na Siedzącego Byka» - przy założeniu, że jest tylko jeden obiekt dostępny wypowiadającemu to zdanie o takim desygnatorze. Po co w ogóle to «ja»? I cóż szczególnego w autoreferencji? Nic bardziej szczególnego niż w dowolnej innej zwrotnej relacji. Czemu np. nie zastanawiać się nad rzekomo ciekawym faktem, że wódz myje siebie?".

Robert Nozick uważa, że osobliwość autoreferencji polega na tym, że odniesienie nie zachodzi ot tak, po prostu, ale z jakiejś racji, a racją tą jest spełnianie jakiegoś warunku (posiadanie określonej własności) ${ }^{15}$. Kiedy formułujemy regułę semantyczną dla „ja”, przypisujemy referentowi własność użycia (wypowiedzenia) „ja”: to dzięki niej ,ja” odnosi się do tego, do czego się odnosi. Tylko że własność ta pojawia się $d z i e ̨ k i$ temu samemu aktowi! $Z$ drugiej strony, podobnie jest $\mathrm{z}$,teraz”, jeśli zgodzimy się, że "teraz” oznacza czas równoczesny z czasem wypowiedzi zawierającej „teraz" ${ }^{16}$ : chwila $t$ staje się referentem „teraz” dzięki równoczesności z czasem wypowiedzi z „teraz”, ale mówienie o równoczesności jest tylko słownym komplikowaniem prostej sytuacji, gdyż nie mamy dwóch chwil (i jedna jest równoczesna $z$ drugą), tylko jedną (podobnie gdy mówimy, że Kloss jest identyczny z Moczulskim, nie oznacza to, że są dwie osoby, z czego jedna jest iden-

14 Por. D. Zahavi, First-person thoughts and embodied self-awareness: Some reflections on the relation between recent analytical philosophy and phenomenology, „Phenomenology and the Cognitive Sciences" 2002, Vol. 1, Issue 1, s. 10.

15 R. Nozick, Philosophical Explanations, Clarendon Press, Oxford 1981, s. 72.

16 Oczywiście o ile „teraz” jest użyte w supozycji zwykłej (niżej też zakładamy ten warunek). 
tyczna $z$ drugą) $)^{17}$. Innymi słowy, chwila $t$ staje się referentem „teraz” dzięki samemu aktowi użycia „teraz” w $t$. Można więc powiedzieć, że słowa podobne do „ja” czy „teraz” odnoszą się bezpośrednio do swych referentów ${ }^{18}$. Jeśli ktoś uważa, że nie, może wpaść w kłopoty podobne do Nozicka, który konsekwentnie uważa, że ja (self) to causa sui - coś, co powołuje siebie (nomen omen) do istnienia w akcie autoreferencji [!] ${ }^{19}$. Z drugiej strony, bezpośrednia referencja dla wielu wygląda „tajemniczo”: właściwie skąd wiemy, że ma miejsce? Czy nie głosimy, że „ja” czy „teraz” są jakimiś „magicznymi” słowami, że nie mogą być „źle użyte” (w sensie: nieodnoszenia się „tak, jak powinny” ${ }^{20}$ ? Niestety, czai się tu wiele trudnych wątków filozoficznych: problem sceptycyzmu i konwencjonalizmu na przykład. Kiedy wyobrażamy sobie wyposażanie znaków językowych w odniesienie do świata przez formułowanie reguł semantycznych w rodzaju „niech «ja» odnosi się do czegokolwiek, co wypowiada zdanie lub inne wyrażenie zawierające «ja»", naturalne jest pytanie o resztę już użytych w tej regule znaków językowych - regres lub błędne koło można zlikwidować przez „przebicie się” do świata, ale to oznacza właśnie uznanie pewnych znaków za „naturalnie odnoszące się"21.

No dobrze, ale czym właściwie jest referent „ja” czy „teraz”? Nawet jeśli te wyrażenia bezpośrednio odnoszą nas do swoich referentów, jakie cechy mają owe referenty? A jeśli nie jest to jasne, to może nie ma mowy o żadnym bezpośrednim odnoszeniu się?

Ktoś może powiedzieć: „rozważ słowo «tu». Jest ono wieloznaczne, co widać w zdaniach typu «tu jest ciemno» czy «tu jest drzazga». W pierwszym przypadku odniesienie dookreśla kontekst - np. gdy wchodzisz do podziemnego korytarza łączącego sieć bunkrów, kiedy to znalazłeś w lesie właz nieużywany od zakończenia ostatniej wojny w pierwszym, w drugim w zasadzie też - o ile w skład

17 Szczególna teoria względności wprowadza tu komplikacje, ale zaczynamy od „codziennej”, „zdroworozsądkowej” analizy. (Co do przykładu, oficer Abwehry Hans Kloss okazał się agentem Stanisławem Moczulskim w popularnej w latach 70. serii komiksowej pt. Przygody kapitana Klossa).

18 Co do ,ja”, wyraźnie wyartykułował to John McTaggart.

19 R. Nozick, Philosophical..., dz. cyt., s. 75. A co np. z czasem? [!]

20 Od czasu Sydneya Shoemakera mówi się w tym przypadku o „odporności na pomyłkę błędnej identyfikacji”.

${ }_{21}$ Zob. J. Haldane, Teoria identyczności umyst-świat a wyzwanie antyrealizmu, tł. S. Judycki, T. Szubka, w: Filozofia brytyjska u schyłku XX wieku, red. P. Gutowski, T. Szubka, TN KUL, Lublin 1998, s. 131, 133; A. Pruss, One Body, Notre Dame University Press, Notre Dame 2013, s. 319; A. Chrudzimski, Teoria intencjonalności Rodericka Chisholma, „Kwartalnik Filozoficzny” 2009, t. 37, nr 3, s. 78 . 
kontekstu wchodzi np. twój palec pokazujący na jedną z kończyn denata w gabinecie zakładu medycyny sądowej. Bez tego reguła «tu» byłaby bardzo mętna, np. «fragment przestrzeni w okolicy użycia 'tu'». Dlaczego nie widzisz w «ja» coś tak podobnie mało zajmującego jak w przypadku «tu»?”.

Odpowiedzieć można na to tak: owszem, przykład z „tu” pokazuje, że tu (sic!) także mamy do czynienia ze zjawiskiem analogicznym do tego związanego $\mathrm{z}$,ja”. Użyliśmy bowiem w domniemanej regule semantycznej dla „tu” wyrażenia „W okolicy użycia «tu»”. Jak określić bliżej znaczenie wyrażenia „okolica”, jeśli nie przez coś podobnego do wyrażenia "tu” albo „tam”? Podobnie, wyżej powiedzieliśmy, że „chwila $t$ staje się referentem «teraz» dzięki samemu aktowi użycia «teraz» $\mathrm{w} t$ " - nie da się zrozumieć, co znaczy, że coś zachodzi w pewnej chwili, bez uprzedniego uchwycenia referenta „teraz”.

Nozick pyta: jeśli znajomość siebie zachodzi wyłącznie dzięki jakiemuś narzędziu referencyjnemu (desygnatorowi, wyrażeniu), to skąd można wiedzieć, że to narzędzie odnosi się do mnie (albo: że ja odnoszę się dzięki niemu do siebie)? ${ }^{22}$ Czy można odpowiedzieć, że wynika z tego, że mamy jakiś przedjęzykowy dostęp do siebie, np. „niemą” (samo)obserwację? Ale skąd wiemy, że obserwujemy siebie? Amerykański filozof rozważa hipotezę, że „ja” jest czymś w rodzaju miejsca zastępującego swój referent, co uważa prima facie za paradoksalne („czy nośnik referencji zawsze musi być obiektem językopodobnym?” - pyta retorycznie $\left.{ }^{23}\right)$, ale gdy przyjrzymy się bliżej, nie różni się to tak bardzo od koncepcji bezpośredniej referencji. Pozostaje jednak jego zdaniem pytanie, skąd wiem, że ów „nośnik” (czyli ja) odnosi się do siebie. Dokonuję pewnego aktu. Ba, ukryte w końcówce czasownika jest już „ja" ${ }^{24}$, zatem jest pewien sprawca (podmiot, nośnik) tego aktu. Skąd jednak wiem, pyta Nozick, że nośnik poprzedzał akt, że istniał przed aktem? Dlaczego nie przyjąć, że zaistniał $z$ aktem ${ }^{25}$ ? Wydaje się, że świadomość retencjonalna, tak plastycznie opisana przez Husserla ${ }^{26}$, byłaby dobrą odpowie-

\footnotetext{
Por. R. Nozick, Philosophical..., dz. cyt., s. 81.

Tamże, s. 82.

Może dlatego Nozick uważa wyżej zasugerowaną hipotezę za prima facie paradoksalną, bo istotnie, fałszem jest, powie ktoś, że Tomasz Kąkol ukryty jest w końcówce czasownika „dokonuję” (gdy tenże Tomasz go wypowiada). Ktoś powie, że dokonaliśmy trywialnego pomieszania języka z metajęzykiem - otóż nie, skoro wedle hipotezy rozważanej przez Nozicka "ja” jest niejako „pustym miejscem” na mnie właśnie.

25 Tamże, s. 87.

26 E. Husserl, Wykłady z fenomenologii wewnętrznej świadomości czasu, tł. J. Sidorek, PWN, Warszawa 1989.
} 
dzią na wątpliwości związane z możliwym nieistnieniem ja przed aktem; aby jednak upewnić się, że rozwiązanie, które ostatecznie proponuje Nozick, jest nie do przyjęcia, przestudiujmy krótko węzłowe punkty teorii amerykańskiego filozofa.

Po pierwsze, Nozick idzie dalej niż „tylko" postulowanie zaistnienia ja „w momencie" dokonania (przez co?) aktu refleksyjnej (czy też pierwszoosobowej) autoreferencji ${ }^{27}$ : pisze o akcie odnoszącym się do siebie, niczym samomyśląca się myśl Arystotelesa albo antynomialne zdanie paradoksu kłamcy. Zgadzam się z Wojciechem Żełańcem, że coś takiego jest niemożliwe, podobnie jak rysująca siebie ręka ${ }^{28}$. Nie jest prawdą, że tylko w przypadku takiego „samostwarzającego się” ja można wyjaśnić zadziwiającą odporność „ja” na błędne odniesienie. Nozick rozważa związany z tym zarzut „momentalności” ja, ale jego odpowiedź jest błędna. Świadomość czy samoświadomość, jak twierdzimy (za Husserlem, ale pierwotne są oczywiście względy rzeczowe, nie autorytet), nie jest dana inaczej jak m.in. w horyzoncie retencjonalnym. To m.in. umożliwia w ogóle refleksję czy autoreferencję refleksyjną, a nie przeszkadza w wyjaśnieniu odporności „ja” na błędne odniesienie! Nozick próbuje „przedłużyć” czasowo swoje „momentalne” ja przez powiedzenie, że ja konstytuuje czy „wbudowuje w siebie” także „pewne przeszłe stadium ja” 29 - pytanie tylko, o które „ja” (self) chodzi? Tym bardziej, że mowa tamże o "przeszłym ja mojego [!] przeszłego ja” (my past self’s past self) i, jak można się domyślać, kolejnych iteracjach. „Po stronie przyszłości” także nie jest lepiej: „ja decyduje, które z rozmaitych przyszłych bytów [...] będą nim [!]”30. Nozick oczywiście jest świadomy ograniczeń w „samostwórczości” ja, choć niechętnie, można powiedzieć, wspomina o nich - np. na s. 667 (przyp. 54) rozważa możliwość, że konstytucja ja zależy od interakcji w ramach wspólnoty - ani

27 W przypadku „Siedzący Byk jest zły na Siedzącego Byka” teoretycznie, tj. czysto językowo patrząc, mogliśmy mieć nierefleksyjną, czy też: trzecioosobową, autoreferencję, ale wódz najprawdopodobniej odnosi się do siebie pierwszoosobowo, może zabrakło mu tylko narzędzi językowych, aby to wyrazić.

28 Przypomina mi się tu słynna grafika Mauritsa Eschera: dwie rysujące się nawzajem ręce. Zob. W. Żełaniec, On the Non-Paradoxality of the Veridic, „Fenomenologia” 2014, nr 12, s. 77-85. Zaznaczam, że Żełaniec nie twierdzi, że każda autoreferencja jest pozorna - nie jest tak np. z czysto językową autoreferencją typu „to zdanie jest napisane po polsku” (tamże, s. 83). Nawiasem mówiąc, Nozick jest świadomy „niestrawności” swojego rozwiązania, gdy pisze: „can the rabbit be pulled out of the rabbit?” (nie „hat”, skoro causa sui!; R. Nozick, Philosophical..., dz. cyt., s. 89), ostatecznie zadowalając się niestety tylko powołaniem się na autorytet Fichtego (,ja ustanawia siebie w samym tym akcie ustanawiania się, i ustanawia siebie jako ustanawiającego siebie, itd."). R. Nozick, Philosophical..., dz. cyt., s. 91.

Tamże, s. 105. 
chybi różnych ja ${ }^{31}$ ! Czy oznacza to, że „pierwsze ja” miały więcej swobody w „autostwórczości"? Czy może odwrotnie, owe interakcje umożliwiają swobodę? Nie mówiąc o tym, że trzeba jakoś odpowiedzieć na zarzut kolistości, choć z drugiej strony trudno oczekiwać tego, skoro już samostwarzanie ja jest jaskrawym przykładem koła. Ostatecznie Nozick uznaje, że ja to pewna własność, a nie podmiot własności [! $]^{32}$. Wydaje się to jeszcze bardziej gmatwać sprawę, niż rozjaśniać, zwłaszcza gdy weźmiemy pod uwagę to, co już rzekomo wiemy o ja dzięki Nozickowi. Czym/kim jestem? Jestem własnością. Jaką? Ja, względnie byciem ja albo - ładniej językowo - byciem mna. Ty też jesteś tą samą własnością co do typu, choć nie co do egzemplarza, stąd mówię, że jesteś byciem tobą. A podmiot tej własności? Jest to... ciało [! $]^{33}$. Siedzi tu przed komputerem pewne ciało, które ma własność... bycia mną? Wydaje się to podpisaniem się pod teorią tożsamości psychofizycznej, czemu przecież przeczy prawie na każdej stronie teoria Nozicka. Trzeba by więc raczej powiedzieć, że to spore ciało ma własność, którą jestem ja. Jestem własnością tego oto ciała. Choć Nozick pisze, jakby śmiejąc się w twarz Leibnizowi i nie tylko, o własnościach wędrujących z podmiotu do podmiotu ${ }^{34}$, można przypuszczać, że jest ona (ta własność) chwilową własnością tego ciała i z nim ginie. Jak się ona ukonstytuowała? Poprzez akt refleksyjnej autoreferencji? Czy może raczej ona jest tym aktem? Ale czy taka identyfikacja jest spójna? Pytania można by mnożyć.

Bardziej umiarkowane stanowisko wydaje się zajmować Lynne Rudder Baker, która wyróżnia kilka stopni, jak je nazywa, pierwszoosobowych zjawisk (lub perspektyw) ${ }^{35}$. Najsłabszy z nich to jej zdaniem posiadanie punktu widzenia (pespektywy). Posiadanie stanów umysłowych w rodzaju przekonań może występować nawet przy braku bardziej wyrafinowanych zdolności od posiadania perspektywy [!]. Językowy wyraz stanu percepcyjnego np. kota byłby czymś w rodzaju, dajmy na to, „[ja] widzę mysz”, ale równie dobrze, zdaniem Baker, można ów stan wyrazić przez „tu jest mysz”. Rola „ja” byłaby bowiem w takim przypadku taka jak rola „tu” (albo „tu i teraz”). Wydaje się, że zamazuje to jednak pewną różnicę: stan „tu jest mysz”, jeśli może wystąpić u kota, może wystąpić

\footnotetext{
Znowu, był to temat popularny u niemieckich idealistów.

Tamże, s. 111.

Tamże, s. 112.

Tamże. Co do Leibniza, chodzi o słynny $\$ 7$. Monadologii.

L.R. Baker, The First-Person Perspective: A Test for Naturalism, „American Philosophical Quarterly" 1998, Vol. 35, No. 4, s. 327-348.
} 
bez stanu „widać mysz" ${ }^{36}$. Po drugie i ważniejsze, przekonanie jest prawdopodobnie czymś więcej niż stanem percepcyjnym. Jeśli zakładać, jak to robi Baker, kocie przekonania, to trzeba by raczej wyrazić podobne do przywołanego przez np. „jestem przekonany, że tu jest mysz”, tylko co począć wtedy z „ja?” Czy można sparafrazować owe rzekome przekonanie przez „tu jest przekonanie, że tu jest mysz?". Sądzę, że stanowisko to byłoby nieco bardziej wiarygodne, gdyby głosiło, że najsłabszym zjawiskiem pierwszoosobowym jest posiadanie perspektywy, co jest związane z występowaniem stanów percepcyjnych, których językowy wyraz obejmowałby wyrażenia okazjonalne przestrzenne i/lub czasowe. Z kolei silnym zjawiskiem pierwszoosobowym, które zdaniem Baker stanowi szczególne wyzwanie dla redukcyjnego naturalizmu, jest nawet nie autoreferencja, ale przypisywanie (innym bądź sobie) autoreferencji ${ }^{37}$. Teza ta faktycznie nie różni się tak bardzo od tezy Nozicka, gdyż jeśli powiemy, że chodzi o refleksyjną czy pierwszoosobową autoreferencję, Baker powinna się, jak sądzę, zgodzić, że jest to równie silne zjawisko. Przekonanie wyrażone w zdaniu „jestem wysoki” (albo: zdanie ,jestem wysoki”, o ile stanowi wyraz relewantnego przekonania) nie tylko jest świadectwem dokonania refleksyjnej autoreferencji, lecz także zawiera, wbrew Baker, przypisanie sobie takowej - skoro bowiem mowa o przekonaniu, jego pełny wyraz brzmi ,jestem przekonany, że jestem wysoki”, to znaczy przypisuję sobie przekonanie (czy jak nazwiemy ten stan umysłowy) o treści wyrażonej przez „ja”, a to już oznacza samoprzypisanie autoreferencji ${ }^{38}$.

Podobnie jak Nozick, Baker bardzo sugestywnie argumentuje za potrzebą uwzględnienia refleksyjnej autoreferencji (w jej terminologii: pełnej czy silnej pierwszoosobowej perspektywy): oślepienie się mitycznego Edypa nie da się wyjaśnić rozumowaniem typu „1. Ktokolwiek zabił Lajosa, powinien być oślepiony. 2. Edyp zabił Lajosa. Ergo: 3. Edyp powinien być oślepiony”, bez uwzględnienia jego przerażającego uświadomienia sobie, że to on sam go zabił (,ja go zabiłem!”) ${ }^{39}$.

36 Por. zabawną parafrazę pewnego sylogizmu praktycznego według recepty Baker, dokonaną przez Johna Perry'ego: „Z przodu w tej filiżance gorąca kawa; tu jest pragnienie i deprywacja kofeiny; zatem pij" (J. Perry, On Knowing One's Self, w: The Oxford Handbook..., dz. cyt., s. 382).

37 L.R. Baker, The First-Person..., dz. cyt., s. 330 i nn.

38 Tamże, s. 328, 330.

39 Zob. R. Nozick, Philosophical..., dz. cyt., s. 72 i nn.; L. R. Baker, The First-Person..., dz. cyt., s. 337 (Baker błędnie sądzi, że zamiast „Edyp” równie dobrze można wstawić wszędzie „ja”). 
Wreszcie, samoświadomość zakłada, zdaniem Baker, zjawiska pierwszoosobowe (pełna samoświadomość - pełną perspektywę pierwszoosobową) ${ }^{40}$. Odkładając na bok zagadnienie świadomości, amerykańska autorka chce dowieść nieredukowalności (pełnej) samoświadomości poprzez nieredukowalność refleksyjnej autoreferencji (relatywnie do stanu obecnej wiedzy, rzecz jasna). Nie zadowala jej np. postulowanie jakiegoś dodatkowego, „szczególnego [...] pierwszoosobowego sposobu przedstawienia", dzięki któremu pewne organizmy mogą refleksyjnie odnosić się do siebie, bo bez dalszych szczegółów, w szczególności - bez zaproponowana mechanizmu powstania takiego sposobu, nie posuniemy się w wyjaśnieniu, tylko poprzestajemy na innej werbalizacji problemu ${ }^{41}$. Dodajmy, że Baker przyjmuje ostatecznie konwencję, by nazywać „pierwszoosobową perspektywą" tylko jej „pełną” wersję̨2.

Zdaniem Zahaviego Baker błędnie opisuje stany percepcyjne; dotyczy to zarówno ekstraspekcji jak i propriocepcji ${ }^{43}$. W pierwszym przypadku wyróżnione jest jedno „tu”, mianowicie perceptor. W drugim natomiast mamy coś bardzo podobnego do „odporności na błędną identyfikację”: nie sposób pomylić się, czy poruszam swoją stopą, czy inną, choć mogę pomylić się, czy oglądam swoją stopę, czy żony ${ }^{44}$. Zresztą kiedy weźmiemy pod uwagę to, że wrażenia propriocepcyjne i kinestetyczne - pomijając przypadki patologiczne - współwystępują z ekstraspekcją, okazuje się, że już „zwykła” percepcja wymaga pewnej samoświadomości. Z jednej strony wydaje się, że spór jest werbalny, bo Baker, jak wspomnieliśmy, wyraźnie pisze o stopniowalności samoświadomości. Zdaniem Zahaviego nie uwzględnia jednak specyfiki stanów percepcyjnych oraz faktu, że to, dla czego rezerwuje nazwę „pierwszoosobowa perspektywa”, jest nabywane przez doświadczenie innych podmiotów. To ostatnie to bardzo delikatny punkt. Klasyczni fenomenolodzy z godnym uwagi wahaniem skłaniają się ku tezie, że tzw. poznanie innych umysłów jest poznaniem bezpośrednim, a nie jakimś rodzajem wnioskowania ${ }^{45}$. Co więcej, twierdzą, że to dzięki uchwyceniu Innych

\footnotetext{
L.R. Baker, The First-Person..., dz. cyt., s. 327 i nn.

Tamże, s. 327, 341, 343, 346, przyp. 30.

Tamże, s. 332.

Zob. D. Zahavi, First-person thoughts..., dz. cyt., s. 11 i nn.

Np. gdy jeszcze jest dość ciemno w pokoju, a nasze słabo widoczne stopy wystają spod kołdry.

45 To samo dotyczy też fenomenologów z nurtu „ucieleśnionego”. Zob. np. D. Zahavi, Subjectivity and Selfhood. Investigating the First-Person Perspective, Bradford Book/MIT Press, Cambridge, MA 2005, s. 186-189; S. Gallagher, D. Zahavi, The Phenomenological Mind..., dz. cyt., s. 178180, 186 i nn. Por. także T. Kąkol, On empathy. E. Stein and R. Ingarden vs cognitive psychology,
} 
dopiero dochodzimy do potraktowania ${ }^{46}$ naszego „żywego tu” (nawiązując do żargonu Husserla ${ }^{47}$ ) jako jednego $\mathrm{z}$ wielu fragmentów przestrzeni ${ }^{48}$. Jak jednak owe inne podmioty stały się podmiotami, jeśli dysponują pełną pierwszoosobową perspektywą? Można to nazwać problemem Pierwszego Podmiotu. Zahavi próbuje go rozwiązać przez wyjaśnienie uchwycenia innych umysłów za pomocą czegoś w rodzaju uprzedniego autowczucia, by tak rzec, tj. percepcji typu Einfuehlung skierowanej na swoje ciało przeżywane pierwszoosobowo ${ }^{49}$. Czy można jednak powiedzieć, że autowczucie generuje czy wyjaśnia refleksyjną autoreferencję? Chyba raczej ją zakłada.

Wniosek byłby taki, że pewna postać refleksyjnej autoreferencji występuje już w przypadku „zwykłego”, percepcyjnego bycia w świecie. Może mylące byłoby tu słowo „refleksyjna”, gdyż nie ma tu mowy o refleksji w sensie stanu umysłowego odniesionego do swojego innego stanu czy innego obiektu umysłowego (gdy np. myślę „gdzie ja wówczas miałem oczy!”), niemniej jednak warto zachować tę konwencję Nozicka, pamiętając, że ma on na myśli to samo, co wyraża określenie „pierwszoosobowa” (Edyp przed poznaniem prawdy o sobie też odnosił się do siebie poprzez „morderca Lajosa”, ale trzecioosobowo). Jeśli od wielu dni po drodze do pracy dostrzegam brudny śnieg, badyle, zakurzone samochody i czołg-pomnik, nie muszę spełniać osobnych aktów, żeby uświadomić sobie, że to moje stany percepcyjne - co innego, kiedy teraz aktowo (czynnie) przywołuję te przeszłe stany. Nie oznacza to jednak, że zanim uczyniłem je obiektem teraźniejszych myśli, stany te były nieświadome lub niczyje (czyżbym, jadąc do pracy, bywał zombi? $)^{50}$. Percepcja i w ogóle stany umysłowe „umysłowymi” zowią się

„Miscellanea Anthropologica et Sociologica” 2019, t. 20, nr 1, s. 36-38, 42 i nn., gdzie próbuję wyjaśnić to „wahanie się”.

46 D. Zahavi pisze mocniej: utożsamienia. Wydaje mi się to przedwczesne. Zob. D. Zahavi, Firstperson thoughts..., dz. cyt., s. 19, 21; tenże, Beyond Empathy. Phenomenological Approaches to Intersubjectivity, „Journal of Consciousness Studies” 2001, Vol. 8, No. 5-7, s. 159 i nn., 162.

47 Husserl mówił o „żywym teraz” - wydaje się, że czas jest z istoty czymś dynamicznym, płynącym, w przeciwieństwie do statycznej przestrzeni. $Z$ drugiej strony jednak przestrzeń też wydaje się konstytuować, nie jest „tępo zastana” (gdy się przyjrzeć sprawie fenomenologicznie, por. fenomen „rozpościerania się”, który w samej nazwie zdradza pewną dynamikę). Zaznaczam, że piszę o „żywym tu”, mając na myśli fenomen „żywego” a dokładniej - „przeżywanego” (z punktu widzenia pierwszej osoby) ciała.

Zob. np. E. Stein, On the Problem of Empathy, tł. W. Stein, ICS Publications, Washington 1989, s. 63. D. Zahavi, Beyond Empathy..., dz. cyt., s. 161, 163.

50 Zob. np. D. Zahavi, Subjectivity and Selfhood..., dz. cyt., s. 21; S. Gallagher, D. Zahavi, The Phenomenological Mind..., dz. cyt., s. 45. 
może właśnie ze względu na tę dziwną własność, że są one tak wyjątkowe jak owe światło ze znanej metafory - oświetlając wszystko inne, oświetlają też siebie ${ }^{51}$. Średniowieczni myśliciele odróżniali refleksję in actu signato i refleksję in actu exercito (vel concomitans); w szeroko rozumianej tradycji Brentanowskiej mowa o świadomości wtórnej (Brentano), praświadomości (Husserl) czy intuicji przeżywania (Ingarden); w tradycji analitycznej ${ }^{52}$ o świadomości preintrospekcyjnej, (samo)świadomości prerefleksyjnej czy implicite ${ }^{53}$. Często jednak wyrażano się w sposób podobny do Nozicka, tj. traktując zbyt dosłownie autoreferencje sta$n u^{54}$. Problem tylko (i aż) w tym, że nie mamy dobrego zrozumienia tej własności i musimy posiłkować się niedoskonałymi metaforami.

Pozostaje jeszcze odpowiedzieć na teorie „redukcjonistyczne”, przy czym - czego czytelnik mógł już się domyślić - przy okazji niejako przedyskutujemy nie tylko nieredukowalność osób, lecz także czasów i miejsc.

${ }_{51}$ Zob. np. D. Zahavi, First-person thoughts..., dz. cyt., s. 17; D. Zahavi, Subjectivity and Selfhood..., dz. cyt., s. 61. Sama metafora, wyeksponowana choćby przez Al-Ghazalego, ma oczywiście źródło w Platońskiej paraboli Słońca.

52 Na marginesie, na dobrą sprawę można by i tę tradycję zaliczyć do Brentanowskiej (pytanie pół żartem, pół serio: czy można pomyśleć Moore’a albo Twardowskiego bez Brentana? Albo Russella bez Meinonga, ucznia Brentana?).

53 Zob. np. R. Poczobut, Rodzaje samoświadomości, „Analiza i Egzystencja” 2008, nr 7, s. 5-31; R. Ziemińska, Samoświadomość i samowiedza z punktu widzenia epistemologii, dz. cyt., s. 33-51.

54 „Na przykład najprostszy akt [...] ma [...] za obiekt wtórny - sam siebie” (F. Brentano, Psychologia z empirycznego punktu widzenia, tł. W. Galewicz, PWN, Warszawa 1999, s. 223); „przy intuitywnym przeżywaniu aktu, to, co poznawane, jest po prostu identyczne z poznawaniem, poznanie jest w tym wypadku uchwytywaniem samego siebie" (R. Ingarden, O niebezpieczeństwie petitionis principii $w$ teorii poznania, tł. D. Gierulanka, w: tegoż, U podstaw teorii poznania, PWN, Warszawa 1971, s. 377). Wychodzi więc na to, że akty (wszystkie, zdaniem Brentana; niektóre, zdaniem Ingardena) mają dwa przedmioty: np. pewne spostrzeżenie długopisu jest zarazem spostrzeżeniem długopisu i siebie [!]. Ktoś mógłby jednak zauważyć, że krytyka „samomyślącej się myśli” odwoływała się do aktu - wspomniany wyżej Żełaniec proponuje czytelnikowi spróbować spełnić akt... odnoszący się do siebie, mający siebie za przedmiot: może w przypadku biernych stanów nie ma żadnego problemu, tylko w przypadku intencjonalnej próby (co właściwie jest pleonazmem) samoodniesienia jesteśmy zmuszeni dokonywać kolejnego aktu (refleksja)? Z drugiej strony jednak mamy „bierny” przykład: znak ostrzegający przed sobą [!] (por. W. Żełaniec, On the Non-Paradoxality..., dz. cyt., s. 83 i nn., przyp. 26), przy czym nie chodzi, jak słusznie podkreśla autor, o nośnik znaku (trójkątny metal na słupku odpowiednio pomalowany), ale o to, co znaczy... no właśnie, co takiego ów znak znaczy? 
David Hugh Mellor potraktowałby powyższą obronę nieredukowalności ja jako pociągającą tezę, że istnieją „perspektywiczne fakty”, tj. „niesuwalnie subiektywne", np. że teraz w Gdańsku jest 14.337 lutego 2019, albo że jestem filozofem (w odróżnieniu od „obiektywnego” faktu, że Tomasz Kąkol jest filozofem, jeśli chodzi o ten drugi przykład) ${ }^{55}$. Tymczasem przekonanie, że jestem filozofem i przekonanie, że Tomasz Kąkol jest filozofem, odnosi się do tego samego faktu z tego prostego względu, że ja = Tomasz Kąkol. Jedyny morał to taki, że faktu tego nie należy utożsamiać z treścią przekonań - treścią pierwszego przekonania jest funkcja przyporządkowująca osobę żywiącą te przekonanie faktowi bycia przez tę osobę filozofem, treścią drugiego zaś funkcja przyporządkowująca osobę żywiącą to przekonanie faktowi bycia przez Tomasza Kąkola filozofem. Theodore Sider twierdzi podobnie: przekonanie to po prostu jedna z relacji między osobą a funkcją od argumentów będących w zależności od zwrotów okazjonalnych występujących w językowym wyrazie tego przekonania - chwilami, osobami, miejscami itp. (Ponieważ bywa, że przekonania się zmieniają, można też mówić o chwilowych relacjach) ${ }^{56}$.

Wydaje się, że ta riposta nie jest zadowalająca. Strategia „w świecie nie ma błędu, może on być tylko w naszych przekonaniach” nie bierze pod uwagę tego, że, paradoksalnie, w ten sposób potwierdza raczej, niż neguje dualizm „świat przekonania" (czy inne stany umysłowe). Nie neguje tu się także osób czy chwil - przeciwnie, potwierdza się z całą mocą ich niezbędność. Owszem, ktoś powie np. „I co z tego? Osoby są tu rozumiane jako solidne, materialne byty, a chwile zgodnie z „obiektywną" teorią czasu, tak zwaną od czasów McTaggarta B-serią: różnica między przeszłością, teraźniejszością i przyszłością jest jedynie różnicą w perspektywie; obiektywnie, ontologicznie są one równorzędne"57. Otóż niezupełnie, gdyż kiedy jestem przekonany, że teraz w Gdańsku jest 14.337 lutego

55 D.H. Mellor, Filozofia analityczna i jaźń, tł. R. Majeran, w: Filozofia brytyjska..., dz. cyt., s. $415-435$.

56 T. Sider, Four-Dimensionalism: An Ontology of Persistence and Time, Oxford University Press, Oxford 2001, s. 18-21. Dokładnie taką samą (Kaplanowską) semantykę zakładają Herman Cappelen i Josh Dever, autorzy pracy pod prowokacyjnym tytułem The Inessential Indexical. On the Philosophical Insignificance of Perspective and the First Person (Oxford University Press, Oxford 2013, s. 16).

57 Por. T. Sider, Four-Dimensionalism..., dz. cyt., s. 21; D.H. Mellor, Filozofia..., dz. cyt. O czasie zob. też M. Łagosz, Realność czasu, Wyd. UWr, Wrocław 2007; J. Gołosz, Upływ czasu i ontologia, Wyd. UJ, Kraków 2011; por. też T. Kąkol, In Defense of Presentism and an Extratemporal God, w: God, Time, Infinity, ed. M. Szatkowski, de Gruyter, Berlin-Boston 2018, s. 53-60. 
2019, albo - aby uprościć przykład - że teraz w Gdańsku jest druga, to wedle tej teorii jestem w pewnej specyficznej relacji do pewnego obiektu matematycznego (funkcji), który obecną chwilę przyporządkowuje byciu w Gdańsku drugą [?], tyle że należałoby sprecyzować w B-języku, o jakiej chwili mówimy. Nie pomoże uwaga „ależ problem jest (albo był, bo go właśnie rozwiązaliśmy) ontologiczny, nie językowy!”, bo mogę zapytać krócej, bez wspominania o języku - o którą chwilę chodzi? Oponent może jedynie odpowiedzieć, podnosząc głos: „o, O TE właśnie”, zakładając tym samym, wbrew sobie, że „teraz” odnosi się bezpośrednio do swojego referenta; względnie może spojrzeć na zegar i powiedzieć, że o chwilę (choć ze względu na uproszczony przykład trudno tu mówić o chwili!) zwaną „druga”. To drugie (nomen omen) jednakże oznacza, że zdanie „teraz w Gdańsku jest druga” znaczy... „o drugiej w Gdańsku jest druga”. Gdyby tak było, po co zegary, skoro zdania o czasie są niczym tautologie? I choć możemy rozważyć zdanie typu „jestem filozofem” i dojść do podobnych wniosków, już w samym opisie przekonania o czasie (czy dowolnego mojego przekonania) mowa przecież o „przyporządkowaniu osobie” - a zatem, o którą osobę chodzi? „Jeśli to Twoje przekonanie, sam przyznałeś, że o Ciebie" - odpowie oponent. No właśnie: spodziewałem się, że powie: „o Tomasza Kąkola”. Kiedy zapytałbym, kim on jest, nie zadowoli mnie odpowiedź wymijająca („nie żartuj, przecież wiesz”) - jeśli usłyszę: „Tobą!”, zapytam, ma się rozumieć, o odniesienie tego wyrażenia; a jeśli usłyszę: „Tomaszem Kąkolem”, to odpowiem, że to wie każdy. „Ależ jeśli chcesz wykazać, że nie jesteś TYM [słucham? którym dokładnie?] materialnym ciałem, tylko jakimś „nie wiadomo, jakim ja”, to argument ten nic nie da. Zgodzisz się przecież, że ja = Tomasz Kąkol, a to już oznacza, że znasz odniesienie tego zaimka osobowego i stroisz sobie ze mnie żarty". Taka riposta ponownie oznacza przyznanie się, że „ja” i podobne wyrażenia okazjonalne odsyłają bezpośrednio do swoich referentów. Nieredukowalność ja (oraz chwil i miejsc) nie jest, powtórzmy, nieredukowalnością odpowiadających im wyrażeń okazjonalnych - język nie wyznacza, z całym szacunkiem dla oponentów ${ }^{58}$, ontologii, inaczej mielibyśmy boską moc powoływania światów słowem do istnienia, a podobno śmiejemy się z ludzi traktujących poważnie historie o czarownicy, która stosownym zaklęciem zamienia księcia w żabę - język raczej próbuje dopasować się, z lepszym lub gorszym skutkiem, do świata. Mówienie o bezpośrednim odsyłaniu to przyznanie,

58 Por. T. Kąkol, Realizm epistemologiczny. Dyskusja $z$ dwoma wybranymi „manifestami antyrealistycznymi” (Goodman, Putnam), „Filo-Sofija” 2014, nr 27, s. 29-41. 
że możemy być pewni istnienia ja, tu czy teraz. Mówiąc słowami Kartezjusza: ja jestem, ja istnieję!

Pytanie tylko: czym jest to ja, które (m.in.) myśli?

Zanim spróbujemy odpowiedzieć na to pytanie, rozważmy jeszcze tylko propozycję Davida Lewisa. Z jednej strony jest ona uznawana za redukcjonistyczną, tj. pokrewną koncepcji Mellora czy Sidera (tak poza tym Lewis jest uznawany za zwolennika tezy o tożsamości psychofizycznej, choć można go też interpretować jako funkcjonalistę ${ }^{59}$ ). $\mathrm{Z}$ drugiej jednak jest ona próbą wykazania, że stany propozycjonalne de se są pierwotne w stosunku do de dicto [!]: „być o czymś przekonanym to przypisywać sobie [podkr. - T.K.] stosowną własność”, np. jeśli jestem przekonany, że śnieg jest biały, to znaczy, że przypisuję sobie własność zamieszkiwania świata, w którym śnieg jest biały ${ }^{60}$. Jeśli jestem przekonany, że jestem Tomaszem Kąkolem, przypisuję sobie własność zamieszkiwania świata, w którym jestem Tomaszem Kąkolem. Mam rację, bo mam tę własność (co innego, gdybym uważał, że jestem np. Napoleonem). Podobnie jest nie tylko w przypadku stanów, w których językowych wyrazach występuje „ja” (lub odpowiednia końcówka czasownika, jak np. w języku polskim), ale i „tu” czy „teraz”. Taki opis zakłada jednak autoreferencję! Co ciekawe, Lewis wypowiada dziwne jak na kogoś, kto twierdzi, że jesteśmy materialnymi częściami świata, słowa: „Bez względu na to, jak wiele mogę wiedzieć o rzeczach tworzących świat [...], wiedza o tym, która z tych rzeczy to $j a$, jest czymś dodatkowym. Ta wiedza de se [...] nie jest wiedzą o tym, jaki jest świat”62. Porównuje też „perspektywiczną wiedzę” do znanej turystom mapy stacjonarnej, na której widnieje kropka (lub inny znak)

59 W planowanej pracy na temat problemu psychofizycznego podejmuję (m.in.) to zagadnienie.

60 Zob. D. Lewis, Attitudes De Dicto and De Se, w: tegoż, Philosophical Papers, Vol. 1, Oxford University Press, New York-Oxford 1983, s. 137. Dokładniej, powinniśmy napisać „jednego ze światów", ale to mogłoby sprawiać błędne wrażenie, że propozycja Lewisa zakłada jego (nie) sławny „ultrarealizm modalny”.

${ }^{61}$ Z „teraz", ściśle rzecz biorąc, jest trochę bardziej skomplikowana sytuacja, gdyż prowadzi to, zdaniem Lewisa, do tzw. perdurantyzmu (w uproszczeniu, tezy, że otaczające nas obiekty takie jak ludzie czy stoły są nie trój-, ale czterowymiarowymi tworami). Zob. tamże, s. 143 i nn. Pominiemy tutaj krytykę tej koncepcji.

62 D. Lewis, Redukcja umystu, tł. M. Iwanicki, w: Analityczna metafizyka umysłu. Najnowsze kontrowersje, red. M. Miłkowski, R. Poczobut, Wyd. IFiS PAN, Warszawa 2008, s. 215. 
z podpisem "tu znajduje się ta mapa"63. Bez tego znaczka mapie zdecydowanie czegoś by brakowało ${ }^{64}$ (nie chodzi oczywiście o tę banalną prawdę, że każdej mapie, jako pewnemu uproszczeniu, czegoś brakuje). Można, rzecz jasna, interpretować Lewisa jako głoszącego po prostu, że eliminacja „perspektywiczności” to eliminacja jakiejś porcji „obiektywności”, bo ta pierwsza to wyróżniony przypadek tej drugiej ${ }^{65}$. Niemniej jednak podejście to albo jest niekoherentne, gdy kontrastuje ze sobą świat i ja (pomijam już tu i teraz), albo zamazuje różnicę między pierwszoosobową i trzecioosobową autoreferencją ${ }^{66}$.

63 Lewis, Attitudes..., dz. syt., s. 138, 144. Zauważmy przy okazji, że o ile np. okrągła tarcza na słupku z napisem „miejsce tego znaku” podpada pod zarzut Żełańca („JAKIEGO znaku?” - można by się zapytać bez nadziei na uzyskanie niekolistej odpowiedzi), to przykład Lewisa zdaje się, wbrew temu, co sugerowaliśmy wyżej w przypisie 54, pokazywać koherencję aktu poznającego siebie, pod warunkiem że poznaje zarazem jeszcze coś innego! Uważam, że warto byłoby to bliżej zbadać. Tamże.

65 Tak to rozumieją Mellor czy Sider. Por. też P. Engel, Czy naturalistyczna teoria umysłu eliminuje subiektywność?, tł. J. Margański, w: Filozofia podmiotu, red. J. Górnicka-Kalinowska, Aletheia, Warszawa 2001, s. 243-259.

66 Por. L. R. Baker, Persons and Bodies. A Constitution View, Cambridge University Press, Cambridge, MA 2000, s. 77, przyp. 35. Co do propozycji Chisholma (zob. tegoż, The First Person. An Essay on Reference and Intentionality, University of Minneapolis Press, Minneapolis 1981) Baker we wspomnianym przypisie słusznie zauważyła, że Chisholm naraża się na taki sam zarzut, co Lewis: zamazanie różnicy między „Mam nadzieję, że Jones przeżyje lot” i „Mam nadzieję, że przeżyję lot" (oba zdania wypowiedziane przez tegoż Jonesa). Zob. też A. Chrudzimski, Teoria intencjonalności..., dz. cyt., s. 82 i nn. Czytelnik może też być ciekawy, co myśleć o jednej z nowszych propozycji, wspomnianej wyżej w przyp. 56. Otóż przede wszystkim autorzy wyrażają się tak, jakby przeczyli sobie, np. wystarczy w cytowanym przez nich $\mathrm{z}$ aprobatą tekście Ruth Millikan podkreślić wszędzie „ja” (por. „It [= „Ruth Millikan” - T.K.] names a person whom I [!] know, under that name, how to manipulate directly... But in order to know how to manipulate this person, why would I [!] need to think indexical thoughts?" - s. 44 i nn.); podobnie na s. 65, przyp. 4 („they”); s. 103 („to himself” w kontekście Lewisowskiego Zeusa); s. 159 i nn. („itself” o kolejnym fikcyjnym bycie, noszącym wszędzie ze sobą lustra); s. 170 (o Johnie, który „fails to recognize himself as himself” [sic!]) czy s. 177 („what we receive through vision is information about the features of, and spatial relations among various objects [among them, us and parts of our body]”). Na s. 135 czytamy, że propriocepcja nie musi dotyczyć „self”, bo może dotyczyć... "the compound bodily parts that belong to self” [podkr. - T.K.]. Słabym argumentem są też eksperymenty myślowe z kręgu science-fiction (s. 131 oraz przyp. 4); zrównanie informacji o „naszych przeszłych ja” z informacjami o innych ludziach [!] (s. 177); branie za dobrą monetę bez argumentu tzw. redukcyjnych teorii tożsamości osobowej (s. 178 i nn.); wmawianie, że sylogizmem praktycznym „kogoś boli; ten ktoś jest w szczególnej relacji ze mną; a zatem powinienem mu ulżyć” posługują się psychopaci [!] (s. 179) czy sugestia, że „,stworzenia, które uciekają przed drapieżnikami tylko wtedy, kiedy egzemplifikują szczególne stany de se „predator-avoiding”, najprawdopodobniej zostaną zjedzone” (s. 180). Autorzy nie dostrzegają też różnicy między Leib a Koerper, o czym więcej niżej. 


\section{Kwestia ciała, czyli ja, Leib i Koerper}

Fenomenologiczna różnica między polem czuciowym a „zewnętrzną” przestrzenią jest faktem, a argumenty za tożsamością psychofizyczną mogą kogoś przekonać, ale tego faktu nie uchylą. Mówiąc o polu czuciowym, chcę za pomocą tego terminu objąć wszystkie tzw. pola wrażeniowe ${ }^{67}$, jak i te dane pierwszoosobowe, które trudno podciągnąć pod pojęcie „wrażenia” ${ }^{68}$. Odczuwam teraz m.in. ucisk na kończyny oparte o stól, krzesło, podłogę $e^{69}$, czuję „pod palcami” klawisze, odczuwam ułożenie części ciała, mam wrażenia słuchowe, wzrokowe (zwłaszcza); czasem miewam coś, co można by nazwać wrażeniem, że kiedyś pomyślałem już myśl, że..., itd. „Żywe tu” rozciąga się tak szeroko, jak pole czuciowe - można tu także użyć znanego w literaturze fenomenologicznej terminu „Leib” (w znaczeniu ciała przeżywanego w pierwszoosobowej perspektywie $)^{70}$. Kiedy teraz patrzę na moje palce przesuwające się po klawiaturze, jestem oczywiście przekonany, że nie jest to ciało np. sąsiada $\mathrm{z}$ trzeciego piętra, ale pod względem przestrzenności, podlegania czynnikom fizycznym (np. oparzenie racą) itp. nie jest to coś radykalnie innego od plastikowych przycisków, (żywych) marchewek czy (żywych) dżdżownic. Fluktuacje pola czuciowego, a więc granic (jeśli można tu mówić o granicach ${ }^{71}$ ) Leib, są dobrze znane - czasem nie potrzeba urazów czy środków

67 Zob. np. R. Ingarden, Spór o istnienie świata, t. II, cz. 2, PWN, Warszawa 1987, s. 200, 212, 224 czy T. Fuchs, Phenomenology and Psychopathology, w: Handbook..., dz. cyt., s. 563 („experiential space”). „Pole czuciowe” nie ma tu nic wspólnego z tak samo brzmiącym określeniem w neuroanatomii, gdzie oznacza część kory mózgowej. Zob. np. W.Z. Traczyk, Fizjologia człowieka $w$ zarysie, PZWL, Warszawa 1989, s. 130, 132, 143, 145, 168 i nn. Anonimowy recenzent zwrócił słusznie uwagę na fakt, że niektórzy (idąc zresztą za pewnymi uwagami Husserla z Idei II) odróżniają od siebie pole wrażeniowe od pola czuciowego. Niestety, nie mogę tu poświęcić miejsca na argumentację za tym, że rozróżnienie to (np. tak, jak je przeprowadza Łukasz Przybylski) jest moim zdaniem nieprzekonujące - do tej kontrowersji mam nadzieję odnieść się w planowanej rozprawie.

68 Por. D.W. Smith, The Circle of Acquaintance..., dz. cyt., s. 96; D. Chalmers, Świadomość i jej miejsce w naturze, tł. R. Poczobut, T. Ciecierski, w: Analityczna metafizyka..., dz. cyt., s. 444.

69 Mimo butów i skarpetek (podobnie czuję ucisk na krzesło, mimo ubrania). Fenomen czucia końcem protezy lub innego urządzenia (por. przykład Ingardena - pilot „czujący” samolotem, Spór..., dz. cyt., s. 199) jest skrajnym przypadkiem tego zjawiska.

70 Husserl niekiedy pole sensoryczne utożsamiał z Leib, por. cytat przytoczony w J.-P. Petit, A Husserlian..., dz. cyt., s. 206, przyp. 10.

71 Przynajmniej o ile granicę rozumiemy jako coś ostro zarysowanego. 
farmakologicznych, żeby zaburzyć jego „typowe” rozpościeranie się $e^{72}$. Biorąc pod uwagę to, co pisaliśmy wyżej, chciałoby się przyznać, że „ja” pierwotnie odnosi się do Leib. Na przeszkodzie stoi jednak fakt, że czasem Leib jawi się jako coś, co - mimo że różny od wszystkiego, co dane poza nim - wykracza niejako poza „właściwe ja”, podobnie jak widziana teraz moja noga (i słyszana - jej ruchy powodują skrzypienie krzesła). Nie tracąc charakterystycznego „zakotwiczenia” czy „częściowego zatopienia” w polu czuciowym, ja może do pewnego stopnia „prześwietlać” czasem dość spore połacie owego pola, „wycofując się”73 niejako z jedności z nim, co jest może mylącym określeniem, ale trudno tutaj o lepsze. „Wycofanie się” można bowiem rozumieć np. jako wypieranie się związku z czymś/ kimś, czy wręcz wypieranie się swojej tożsamości. Kiedy np. patrzę rano w lustro i jestem zatrwożony moim Koerper danym wzrokowo, mogę wykrzyknąć (jak w kultowym Misiu) „ta obrośnięta małpa z czarnym ryjem to mam być ja?!” Niemniej jednak, „ja” w tym użyciu jest podobne do „ja” w przypadku wypowiedzi typu „lecę do Bostonu” - nie znaczy to, że lecę o własnych siłach, ale szczelnie zamknięty w odrzutowcu ${ }^{74}$. Nie znaczy to też, że ja pierwotnie należy rozumieć jako coś, co mieści się w Koerper jak np. mózg w czaszce, gdyż mózg też jest częścią Koerper (także żywy mózg - np. pacjenta podczas trepanacji albo mój, dany mi pośrednio na monitorze funkcjonalnego rezonansu magnetycznego). „Wycofywanie się z jedności z polem czuciowym” niekoniecznie występuje, jak można by się spodziewać, np. gdy oddajemy się „abstrakcyjnym”, jak to się mówi, problemom (np. jak sformalizować jakieś rozumowanie Kartezjusza) - wtedy można bowiem interpretować ten stan jako pewnego rodzaju zapomnienie o owej jedności (mniej więcej w takim sensie, w jakim zapominam, że mam rękę bądź

72 Por. choćby słynną „iluzję gumowej ręki” (zob. np. M. Tsakiris, The Sense of Body Ownership, w: The Oxford Handbook..., dz. cyt., s. 182; popularny opis jest np. w „Świecie Nauki” 2008, $\mathrm{nr}$ 1(9) [wydanie specjalne]) czy nawet coś przypominającego OBE (out-of-body-experience) bez użycia przezczaszkowej stymulacji czy tym podobnych technik (M. Tsakiris, The Sense..., dz. cyt., s. 197). Pacjenci pozbawieni poczucia prawie całego ciała to IW, Christine czy LB (zob. np. J. Cole, Agency with Impairments in Movement, w: Handbook..., dz. cyt., s. 655 i nn.; J. Bremer, Osoba..., dz. cyt., s. 429 i nn.; A. Damasio, Tajemnica świadomości. Ciało i emocje wspóttworza świadomość, tł. M. Karpiński, Rebis, Poznań 2000, s. 230 i nn.).

73 S. Judycki pisze w tym przypadku o „dystansowaniu się”. Zob. tegoż, Świadomość i pamięć. Uzasadnienie dualizmu antropologicznego, TN KUL, Lublin 2004, s. 106, 311, 314. Podobnie A. Chmielecki, Między mózgiem a świadomością. Próba rozwiązania problemu psychofizycznego, Wyd. IFiS PAN, Warszawa 2001, s. 80.

74 Por. U. Meixner, Classical Dualism Modernized. A Proposal, w: Dualistic Ontology of the Human Person, red. M. Szatkowski, Philosophia Verlag, Muenchen 2013, s. 17. 
bieliznę na sobie - po prostu „żyję z nią w jedności”), gdyż ja pochłonięte jest czymś zupełnie innym. Paradoksalnie, w moim przynajmniej przypadku stan, w którym ja wyraźnie odcina się od przynajmniej części pola czuciowego, występuje w przytłumionych stanach świadomości, np. w pewne noce, między jawą a snem. Np. wczoraj położyłem się do łóżka, mając świadomość „zdominowaną” przeżyciem czegoś, co nieporadnie można by nazwać „zmęczeniobólem” (bo był to wyraźny splot uczucia silnego zmęczenia i uczucia bólu), lokalizującym się fenomenalnie (więc z mocno rozmytymi granicami) w głowie, $\mathrm{z}$ wyraźnym nasileniem w okolicach gałek ocznych. Prócz zwykłych doznań typu dźwięk oddechu i bicie serca zaznaczył się dobrze mi znany niezwykle delikatny ${ }^{75}$ szum, który przejściowo zmienił swą „barwę i ton”, by za chwilę powrócić do poprzedniego stanu, co neurofizjolog by wyjaśnił np. chwilowym odkształceniem się trąbek słuchowych. Ów delikatny szum z pewnym wahaniem mógłbym porównać do szumu wydawanego przez znaną osobom mojego pokolenia suszarkę "farelkę", używaną do usypiania dzieci. Jej skuteczność tłumaczono generowaniem wrażeń, które dziecko doznawało w łonie matki (ciepło połączone z szumem krwi $\mathrm{w}$ naczyniach krwionośnych matki ${ }^{76}$. Myśli wyrażone w tych zdaniach również pojawiły się „w kontekście” nocnych doznań, o których tu teraz piszę, choć w formie bardziej „rozmydlonej”, czemu zresztą trudno się dziwić, gdy świadoma kontrola była ograniczona. Najciekawszy w tym wszystkim był właśnie fenomen ja „wyłączającego się” (przynajmniej częściowo) z doznańn ${ }^{77}$, co teraz, na jawie, można zinterpretować moim zdaniem tak: ja traktuje doznania (wrażenia i inne dane pierwszoosobowe) jako nie różnicujące między Leib a „resztą świata” w tym sensie, że to, co nazwałem "delikatnym szumem”, jak i to, co pojawia się teraz w postaci słuchowych doznań (np. szum pojazdów z obwodnicy), konstytuuje sferę Leib (pole czuciowe) bez „skoku jakościowego" między tym, co potraktowane jako „płynące z ciała” (np. „przemęczony mózg”, „pulsująca krew”), a tym,

75 Wyraźnie odróżnia się on od intensywnego szumu, który może parę razy w życiu pojawił się w stanach wyraźnie patologicznych (skrajne przemęczenie, gorączka, uboczne skutki podania pewnych leków). Ten drugi miał jakościowo odmienny charakter.

76 Na marginesie, dla ciekawych: byłem zaskoczony, kiedy Rafał Palczewski wskazał mi na ogólnodostępne nagrania „farelki” - zob. np. https://www.youtube.com/watch?v=SDuEcDTPITM, dostęp: 27.02.19, uwaga: na tym filmiku nie widnieje oryginalna, pomarańczowa „farelka” z lat 70.

77 Już po napisaniu relacji z mojego doświadczenia ,ja wycofującego się z pola wrażeń”, podobny opis znalazłem u Maine de Birana dzięki D. Legrand (zob. D. Legrand, Phenomenological Dimensions of Bodily Self-Consciousness, w: The Oxford Handbook..., dz. cyt., s. 210). 
co potraktowane jako „płynące z okolic” („świst wiatru w kominie”, „szczekanie psa za oknem”). Krótko mówiąc, ja nie sposób utożsamić bez reszty z Leib, z perspektywy pierwszej osoby.

Oczywiście, ideałem byłaby sprawdzalność tego opisu w stopniu zbliżonym do sprawdzalności reakcji nogi pacjenta na uderzenie poniżej rzepki - inaczej, powie ktoś, jesteśmy zmuszeni do czegoś w rodzaju wierzenia na słowo opisującemu swój sen. Analogia ta jednak, powie fenomenolog, jest jednak nietrafna, gdyż nie chodzi o idiosynkratyczne doznania, ale o typowe - „zweryfikuj to sam na sobie, jak nie wierzysz". Jeśli ktoś twierdzi, że problem w tym, że ktoś może powiedzieć „sprawdziłem i nie widzę tego, co ty”, to nie ma szans na dojście do jakiejś neutralnej instancji, która by rozsądziła spór. Możemy co prawda kierować się zgodnością (zawsze przybliżoną) relacji z refleksji fenomenologicznej, ale - podobnie, jak w przypadku snu - nie da się wykluczyć (pomijając już nieszczerość), że relacjonujący nie dostrzegł czegoś, co powinien (jeśli „przedmiotowa” analiza snów jest trafna, w co można wątpici ${ }^{78}$ ) albo po prostu szybko zapomniał, czego doznał (jak w przypadku często nawet bardzo wyrazistych snów - z każdą sekundą po obudzeniu zdolność jego odtworzenia u mnie stopniowo się zaciera).

Skonfrontujmy powyższy opis z klasyczną analizą niektórych aspektów problemu psychofizycznego zawartą w paragrafach 76-79 Sporu... Ingardena ${ }^{79}$. Kluczowe moim zdaniem w tym doskonale znanym (przynajmniej wśród polskich fenomenologów) tekście są następujące spostrzeżenia:

Cokolwiek by twierdzić o domniemanych przerwach w strumieniu świadomości, „u podstawy” domniemanej jedności strumienia świadomości leży „tożsamość przeżywającego ja” ${ }^{80}$. „Czując przerwę w toku przeżyć [np. w przypadku snu bez marzeń sennych - T.K.], nie odczuwamy jej wcale w naszym istnieniu" ${ }^{\text {. }}$. Ingarden doskonale wie, że czym innym jest problem uprawomocnienia tego

\footnotetext{
78 Tj., że w śnie nie „projektujemy” (przynajmniej do pewnego stopnia) doznań, ale napotykamy przedmioty, których aspekty można dostrzegać albo i nie, tj. w tym drugim przypadku pozostają one "niedostrzeżone”. Oczywiście, nie znaczy to, że „przedmiotowa” analiza snów zakłada, że obiekty śnione są realnymi przedmiotami, np. gdzieś teraz lub w przeszłości (lub przyszłości? A może na innej planecie?) istniejącymi domami.

79 R. Ingarden, Spór o istnienie świata, t. II, cz. 2, PWN, Warszawa 1987, s. 141-236.

80 Tamże, s. 162.

81 Tamże.
} 
doświadczenia (należy on do „epistemologii”»2); w każdym razie przestałbym normalnie funkcjonować, „gdyby choć na chwilę tego poczucia zabrakło”"83. Rozważmy też popularny niegdyś pogląd ${ }^{84}$, że ja jest niepoznawalne w tym sensie, że owszem, jest założeniem wszelkiego poznania, ale z definicji niejako nie może być przedmiotem poznania (bo jest podmiotem tegoż). Teza ta jest równoważna temu, że relacja poznawania nie może być zwrotna - pytanie tylko, skąd to wiemy. Gdyby jednak o ja nie można było nic wiedzieć, to skąd mogę wiedzieć, że np. teraz myślę, ba, że myślę ja, a nie ktoś inny? - pyta retorycznie Ingarden ${ }^{85}$. Niemniej jednak termin „ja” jest systematycznie wieloznaczny w tym sensie, że jego desygnaty można zdaniem autora Sporu... tak oto uporządkować: (a) ja jako podmiot świadomy, bez zakładania czegokolwiek innego; (b) ja jako złożone centrum osoby (przy czym należy zapytać, co to jest osoba); (c) ja jako istota umysłowa; (d) ja jako istota psychofizyczna, przy czym nawet w obrębie aspektu fizycznego granice ja nie są ostre (por. wyżej, przykład z odrzutowcem, choć Ingarden ogranicza się do wskazania na ubranie ${ }^{86}$ ). Derek Parfit wraz z innymi pytał, skąd wiemy, że dalej jesteśmy tym samym ja ${ }^{87}$. Owszem, nie czuję przerwy w istnieniu między ja wczorajszym a ja dzisiejszym, powiedziałby, ale - pomijając możliwość złudzenia - czuję, że mówiąc o mnie, że np. płakałem jako pięciolatek, mówisz o kimś innym: tu czuję może nie przerwę, ale po prostu różnicę, jaką ty czujesz, kiedy ktoś mówi o dwóch różnych osobach (i ty wiesz, że one są różne).

Wielu próbowało polemizować z Parfitem (ale też wielu Parfit przekonał [sic!]), niemniej jednak trudno polemizować z czuciem. Można odwoływać się do czuć innych (i próbowano to robić; inna sprawa, czy przypadkiem rzekomego potwierdzenia teorii Parfita ${ }^{88}$ nie osiągnięto przez podsuwanie respondentom sugestywnych pytań), ale moim zdaniem nie da się tego interpretować inaczej niż jako przypadek amnezji, gdyż alternatywne wyjaśnienie przypisuje trywialny

\footnotetext{
Tamże.

Tamże.

${ }^{84}$ Wiązany z Kantem (nb. Ingarden polemizuje w tym kontekście z neokantystą Paulem Natorpem). Dziś broni go Andrzej Chmielecki. Zob. A. Chmielecki, Między mózgiem..., dz. cyt., s. 80.

85 R. Ingarden, Spór..., dz. cyt., s. 168.

86 Tamże, s. 170.

87 Wątpliwości wprowadziły tu rozważania Johna Locke’a czy Davida Hume’a.

88 Zob. pracę Raymonda Martina, Self-Concern. An Experiential Approach to What Matters in Survival, Cambridge University Press, Cambridge, MA 1998.
} 
błąd (projektującą definicję „ja”, np. „to, z czym czuję się mocno psychologicznie powiązany", co zresztą jest koliste) ${ }^{89}$.

Mówiąc jednak o amnezji, mówimy o pamięci; pamięć jednak nie jest jako taka przeżyciem, ale pewną dyspozycją. Ja traktowane wyłącznie jako podmiot przeżyć (oraz jego przeżycia) nie wystarcza. Podobnie, kiedy staję, mówiąc przenośnie, przed dylematem (pisać mimo zmęczenia czy iść spać) i doznając wysiłku, wybieram (pisać!), mam splot nierzadko „sprzecznych” przeżyć (zmęczenie, ból, bezradność, gniew, nadzieja, przeżycie siły, ulga... pomijam typowo „percepcyjne" przeżycia, np. postrzeżenia wzrokowe), z których kotłowaniny różne przebijają się na pierwszy plan, aby za chwilę ustąpić miejsca innym. Przeżycie siły nie jest jednak siłą, podobnie jak pamięć (w przeciwieństwie do aktu przypomnienia sobie na przykład) nie jest przeżyciem. Siła czy zdolność wyboru to dyspozycje. Przeżywające ja jest więc pewną abstrakcją, także z tego powodu, że przeżywanie jako pewna aktualna charakterystyka ja (np. kiedy teraz percypuję, myślę itp.) zakłada zdolność, dyspozycje właśnie owego ja do wykonywania tych rzeczy. W tym sensie ja jest złożone (zob. „ja” sub (b)). I w tej złożoności, w wielu swoich aspektach, trudno poznawalne, jak to już było napisane na ścianie delfickiej świątyni, ba, czasem „bardzo obce”"

A czy jest unikalne? Czy może przeciwne, może mieć „sobowtóra”? Intuicyjna odpowiedź brzmi: w żadnym wypadku ${ }^{91}$. Wyobraźmy sobie zresztą spotkanie ze swoim rzekomym „sobowtórem”. Wchodzi teraz do pokoju zdziwiony człowiek, który wygląda jak moje odbicie lustrzane. Jestem przerażony, że ma takie same nerwowe ruchy i taki sam denerwujący głos, który czasem słyszę na nagranym po cichu przez dziecko filmiku. Na moje pytania o sprawy, o których tylko (jak mi się wydaje) ja wiem, odpowiada zgodnie z prawdą ${ }^{92}$. Zresztą nie musi to być,

89 Por. G. Madell, The Essence of the Self. In Defense of the Simple View of Personal Identity, Routledge, New York-London 2015, s. 74. Zgadzam się z Zahavim, że „tożsamość ja (self) definiuje się w terminach dania (giveness) raczej niż czasowej ciągłości” (D. Zahavi, Unity of Consciousness and the Problem of Self, w: The Oxford Handbook..., dz. cyt., s. 328 i nn.). Por. też tegoż, Subjectivity and Selfhood..., dz. cyt., s. 234 i nn., przyp. 14, gdzie Zahavi formułuje identyczny argument jak Ingarden (nie znając prawdopodobnie Sporu...) przeciwko koncepcji „sekwencji ja” przedzielonych całkowitą nieświadomością (zob. R. Ingarden, Spór..., dz. cyt., s. 153-158, 161-163).

$90 \quad$ R. Ingarden, Spór..., dz. cyt., s. 187.

91 Tamże, s. 186 i nn.

92 Mistrzowsko opisał podobną sytuację Fiodor Dostojewski w Sobowtórze właśnie. 
powie ktoś, duplikat umysłowo-fizyczny ${ }^{93}$ : a zatem załóżmy, że ma wygląd zupełnie nieznanego mi człowieka, ale zachowanie, relacje z rzeczy „osobistych” itp., wszystko „się zgadza”. Czy zachwiałoby to moim poczuciem tożsamości? Czy mogłoby tak być, że rozmawiałbym ze sobą? Otóż nie. We wczuciu dana mi jest jego psychika (a może jednak to filozoficzny zombi?); nie wiem jednak, co mu jest dane ze mnie, póki go o to nie zapytam - owszem, relacjonuje mi rzeczy, które nikt z ludzi poza mną (i żoną, ale jej wierności jestem pewien jak ego cogito Kartezjusza), jak mi się wydaje, nie może wiedzieć (np. ile razy współżyłem z żoną - czyżby włamywacze nie zostawiający śladów znaleźli mój tajny notatnik?), ale $\mathrm{z}$ tego jeszcze nie wynika w żadnym razie, że to $j a^{94}$. „No ale skąd wiesz, że to jednak nie Ty!” - powie ktoś. „Z tego, że nie wynika, możesz co najwyżej wywnioskować, że nie wiesz, że to Ty, ale nie, że wiesz, że to nie Ty". Owszem, ale wtedy wystarczy, bym np. wyjechał do Włoch, a moje rzekome „drugie ja” - na Hawaje $[!]^{95}$.

Wracając do Ingardena, polski fenomenolog przyjmuje konwencję terminologiczną, by mocno obciążonego wyrazu „dusza” używać na oznaczenie podmiotu dyspozycji umysłowych i cech charakteru. Podmiot ten jednak to po prostu ja, tyle że nie ujęte już tylko w aspekcie bycia podmiotem przeżyć. „Osobą” ma się z kolei nazywać dusza, w której „kierowniczą rolę” pełni właśnie ów podmiot

93 Pojęcie „duplikat umysłowy” jest tak poza tym sprzeczne, o ile to, co umysłowe, uważa się za ściśle związane czy wręcz tożsame z perspektywą pierwszoosobową, co zresztą jest trafne fenomenologicznie. Niektórzy dualiści dziwnym trafem tego nie widzą. Zob. np. R. Swinburne, The Structure of the Soul, w: Persons and Personality. A Contemporary Inquiry, eds. A. Peacocke, G. Gillett, Basil Blackwell, Oxford 1987, s. 51, 55; G. Madell, The Essence..., dz. cyt., s. 92 i nn.

94 Nawiasem mówiąc, gdyby faktycznie ktoś taki teraz tu wszedł, pomyślałbym, że to halucynacja lub jakaś wizja „nadprzyrodzona”, diabeł, anioł itp. (muzułmanin mógłby pomyśleć podobnie, uwzględniając jeszcze dżinny; hinduista lub buddysta - zależnie od szkoły - także by miał w pogotowiu jakiś pakiet „dopuszczalnych istot” itp.).

95 Nie może w żadnym przypadku być tak, by np. stan świadomy widzenia czerwonych maków na błękitnym tle nieba i symultaniczny (albo prawie symultaniczny, jeśli ktoś chce, by uwzględnić fizycznie możliwy limit prędkości, choć - z uwagi na niewielką odległość - nie jest to istotne) stan świadomy widzenia Wenus czarną nocą na niebie były stanami tego samego podmiotu ludzkiego (pomijamy tu oczywiście dostęp zapośredniczony przez np. urządzenie telekomunikacyjne). Jeśli ktoś powie, że jest to możliwe, tyle że stany te są „wzajemnie niedostępne”, to sytuacja taka nie różni się od przypadku dwóch osób/podmiotów, np. prezydenta Włoch kontemplującego drogę na Rzym i prezydenta USA kontemplującego w tym czasie hawajskie niebo. Nie pomoże tu zapewnienie, że może tu istnieć „pozaempiryczna różnica”, o ile nie ma niczego w podmiotowości, co by wykraczało poza punkt widzenia pierwszej osoby. 
przeżyć ${ }^{96}$, co sugeruje, że dusza może istnieć bez takiego ustroju, co brzmi co najmniej dziwnie. Można to rozumieć tak, że „nieosobowa (jeszcze? już?) dusza”, jeśli tak można powiedzieć, występuje w stanach nieświadomości lub/i w jakichś schorzeniach psychicznych, ale interesujące są tu problemy rzeczowe, nie terminologia. Ingarden słusznie pisze o „wrażeniach wewnętrznych”, że „jakby” rozciągnięte są $\mathrm{w}$ ciele (dlatego pokazuję lekarzowi, gdzie mnie boli97) - chodzi o ciało w sensie Koerper, same wrażenia konstytuują ostatecznie Leib ${ }^{98}$. Ja w szerszym tego słowa znaczeniu (sub (c), a zwłaszcza sub (d)) jest systemem, „którego równowaga jest zawsze w pewnym stopniu chwiejna" ${ }^{99} \mathrm{w}$ tym sensie, że różne aspekty (Leib, Koerper, ja „czyste”) mogą uzyskiwać w nim „przewagę”, czy wręcz: pozostawać w domniemanym konflikcie. Przykładów jest mnóstwo: ja nie chce "przyjąć do wiadomości”, że „jej” Koerper nie jest już posiadaczem bujnej czupryny (szampon „Samson” okazał się niewypałem); narastające określone wrażenia cielesne niepokoją „czyste” ja (co zresztą prowadzi do pojawienia się innych wrażeń cielesnych), a niepokoją z powodu obserwatorki Koerper, podczas gdy Koerper zaczyna w pewnych miejscach drżeć, co powoduje, jak się wydaje, wyraźny niepokój na twarzy tejże obserwatorki itd.; zmęczenie i ból oczu rozlewający się po Leib doprowadza ja do przerwania pisania itd.

Ingarden zadaje pytanie: czy można zapytać, gdzie podjąłeś decyzję, by pisać dalej, tak jak można zapytać, gdzie mniej więcej czujesz ból (teraz? okolice oczu)? Odpowiada, że pytanie to nie ma sensu ${ }^{100}$. Można jednak ripostować, że nikt nie powie, że np. w krześle bądź nodze ${ }^{101}$. Ja „czyste”, zdaniem Ingardena, „w jakiś sposób” znajduje się w ciele ${ }^{102}$, choć - podobnie jak wrażenia - „bez żadnej jednak bliższej lokalizacji”" ${ }^{103}$. Nieprzypadkowa jest sugestia, że ja, jeśli w ogóle, jest „w okolicach głowy”"104, ale nie wynika to z rzutowania na nasze doświadczenie odkryć neuronauk, ale, jak trafnie zauważył Chmielecki, z umiejscowienia narządów zmysłów (głównie oczu). Oto jego eksperyment myślowy: nasze nerwy są rozciągliwe i ktoś bezboleśnie (i „cudownie” zapobiegając krwotokom itp.) wyj-

\footnotetext{
R. Ingarden, Spór..., dz. cyt., s. 191.

Tamże, s. 196.

Tamże, s. 213 i nn., zwłaszcza przyp. 86.

Tamże, s. 202.

100 Tamże, s. 211.

101 Tamże, s. 213.

102 Tamże, s. 211.

103 Tamże, s. 213.

104 Tamże.
} 
muje nasz mózg i pokazuje go nam (nie przerywając unerwień z „resztą nas”) doświadczenie domniemanego „umiejscowienia ja” nie zmieni się! Gdyby z kolei wyjąć w podobny sposób nasze oczy i odwrócić je, doznalibyśmy czegoś w rodzaju przeżycia autoskopicznego ${ }^{105}$. Z drugiej strony, słuchu i czucia wewnętrznego (zwłaszcza mocno unerwionej twarzy) też nie można zaniedbywać: podczas moich nocnych przeżyć opisanych wyżej, przy braku wyraźnych doznań wzrokowych, jeśli musiałbym użyć jakiejś wzrokowej metafory zapytany o lokalizację ja, opisałbym je jako otoczone czy otulone przez „fenomenalną głowę”, czy może jeszcze bardziej zmysłowo: ja niczym głowa otulona czapką i szalikiem doznań. Okolice głowy wyraźnie się narzucają ${ }^{106}$.

Podsumując, ja wyodrębnia się choć nie odrywa od pola czuciowego, to z kolei kontrastuje z tym, co dane jako widziane teraz palce, słyszany stukot klawiatury, co więcej, słyszane teraz krążenie mojej krwi w głowie i odczuwany nacisk na opuszki palców. Ingarden sprawia wrażenie, że utożsamia Leib z Koerper i niestety nie jest w tym odosobniony: widziany „od zewnątrz” kawałek Koerper, palec, jest zarazem „odczuty od wewnątrz”, więc stanowi fragment Leib ${ }^{107}$. Owszem, można powiedzieć, że widzę palec i odczuwam ten sam palec, ale wrażenie wzrokowe jak i wrażenie czuciowe (propriocepcyjne, kinestetyczne itp.) nie jest palcem, podobnie jak wrażenia wzrokowe, które mam, patrząc na ekran, nie są ekranem. Trudno zresztą oczekiwać od myśliciela tej klasy co Ingarden przejścia na (krytykowane przecież przez niego gdzie indziej) stanowisko idealistycz-

105 Zob. A. Chmielecki, Między mózgiem..., dz. cyt., s. 12. O doświadczeniach autoskopicznych zob. np. A.L. Mishara, Autoscopy: Disrupted Self in Neuropsychiatric Disorders and Anomalous Conscious States, w: Handbook..., dz. cyt., s. 591 i nn.

W przypadku śniącej świadomości także użyłbym pojęcia „fenomenalnej głowy” jako czegoś „utkanego z czuć”, choć jest to mniej wyraźne, a w każdym razie zależy od snu. Np. w jednym śnie przeżywam siebie jako mającego „głowową" lokalizację poczucia ja, np. w jednym z nich czuję przystawione do głowy zimne lufy pistoletów (zapewne wpływ oglądanych filmów kryminalnych), w innym - a czasem tym samym - zmienia się nagle mój punkt widzenia i w ogóle przeżywania tak, że mam wrażenie autoskopiczne (poczucie oglądania i przeżywania siebie występuje pomimo odmienności wyglądu ciała! Choć pamiętam tylko jeden jedyny przypadek, jeszcze z dzieciństwa, gdzie nie miałem ciała ludzkiego, lecz... kocie. Nienaturalne powiększenie lub pomniejszenie - a przynajmniej przeżywane jako takie, deformacje czy nawet rozkładanie się, już częściej. Niewrażliwość na strzały, na grawitację - a przynajmniej do pewnego stopnia - to znane rzeczy wielu śniącym). 
ne czy fenomenalistyczne, utożsamiające przedmiot percepcji z wiązką wrażeń. Współcześnie raczej, jak wiadomo, dokonuje się identyfikacji wrażeń czy czuć z procesami neurofizjologicznymi („czymś fizycznym”), czego Ingarden nie przyjmował, choć, jeśli go dobrze interpretuję, dopuszczał ${ }^{108}$. Jest zresztą charakterystyczne, że przedstawiciele „fenomenologii ucieleśnionej”, choć dobrze znają różnicę między Leib a Koerper, czasem wyrażają się w sposób zdumiewający. Bliski skądinąd „fenomenologii ucieleśnionej” José Luis Bermudez lekceważy tę dystynkcję ${ }^{109}$, oświadczając przy okazji, że „czucie i wrażenia są doświadczane tylko w granicach ciała"110 - zapewne chodzi o Koerper, gdyż Leib wyznaczony jest właśnie przez pole czuciowe. Pytanie tylko, co wyznacza granice Koerper ${ }^{111}$. $\mathrm{Z}$ jednej strony twierdzi, że „przestrzenność cielesnego doświadczenia (bodily experience) jest fundamentalnie inna niż przestrzenność naszego doświadczenia świata"112, ale ostatecznie sprowadza się to, jego zdaniem, do różnych układów odniesienia $^{113}$. Wspomniana na samym początku niniejszego eseju Legrand także doskonale zna różnicę między Leib i Koerper ${ }^{114}$, ale ostatecznie ją przekreśla ${ }^{115}$. Zacytujmy jeszcze raz Gallaghera i Zahaviego, którzy starannie odróżniając Leib i Koerper, konstatują, iż „co opisujemy jako przeżywane (lived) ciało z perspektywy fenomenologicznej, jest dokładnie tym samym ciałem, co ciało biologiczne, które badamy z perspektywy obiektywnej"116. Jeśli jednak wrażenia istotnie są

108 R. Ingarden, Spór..., dz. cyt., s. 210, 218 (zwł. przyp. 93), 220, 226-228.

109 J. L. Bermudez, Bodily Awareness and Self-Consciousness, w: The Oxford Handbook..., dz. cyt., s. 158 i nn., 175.

110 Tamże, s. 164.

111 Najprościej wskazać na skórę, ale - nawet pomijając koncepcje tzw. umysłu rozszerzonego (zob. np. A. Clark, D. Chalmers, Umysł rozszerzony, tł. M. Miłkowski, w: Analityczna metafizyka..., dz. cyt., s. 342-357; w planowanej rozprawie odniosę się także do tej propozycji) - jest to do pewnego stopnia arbitralne, a poza tym problem się tylko przesunie, gdy zapytamy o granice skóry. Por. też prace Erica Olsona, który to, utożsamiając ja z Koerper (rozumianym jako biologiczny organizm), próbuje znaleźć jego granice, dochodząc do szokujących wniosków (np. że nie istnieją mózgi i kończyny [!], czy postulując odrzucenie terminu „body” jako wprowadzającego w błąd); zob. tegoż, Why I Have no Hands [i nie tylko - T.K.], „Theoria” 1995, Vol. 61, No. 2, s. 182-197; tegoż, A Compound of Two Substances, w: Soul, Body and Survival, ed. C. Corcoran, Cornell University Press, Ithaca and London 2001, s. 73-88; tegoż, Is There a Bodily Criterion of Personal Identity?, URL: https://www.sheffield.ac.uk/polopoly_fs/1.101671!/file/BodilyCriterion.pdf, dostęp: 22.08.2019).

112 J. L. Bermudez, Bodily Awareness..., dz. cyt., s. 176.

113 Tamże, s. 175-177.

114 D. Legrand, Phenomenological Dimensions..., dz. cyt., s. 209.

115 Tamże, s. 222

116 S. Gallagher, D. Zahavi, The Phenomenological Mind..., dz. cyt., s. 140. 
pewnym specyficznym rodzajem procesów neurofizjologicznych, to jeśli ja nie utożsamimy po Hume'owsku $\mathrm{z}$ wiązką wrażeń ${ }^{117}$, nie dokonamy utożsamienia istotnego dla teorii tożsamości psychofizycznej, gdyż z rozważań, jakie przeprowadziliśmy, zagadnienie psychofizyczne nie sprowadza się do odnalezienia „jak” między dwoma, ale między trzema członami: ja, polem czuciowym i Koerper.

Znawcy „fenomenologii ucieleśnionej” mogą jednak zauważyć, że status wrażeń jest tu problematyczny. Będą ochoczo podkreślać za takimi choćby krytykami fenomenologii jak Daniel Dennett, że nie istnieją qualia rozumiane jako obiekty „atomiczne, nierelacjonalne, niewyrażalne, nieporównywalne i niekorygowalne"118. Tyle że dawno przed Dennettem zauważono, że tzw. czyste dane wrażeniowe są pewną abstrakcją - nawet w specjalnie dobranych warunkach (ciemne pomieszczenie, rozbłyski monochromatycznego światła) umysł zdaje się $e^{119}$ spontanicznie dokonywać „przedmiotowej interpretacji” wrażeń („widzę coś jakby zieloną eksplozję”) z jednej, „synchronicznej” niejako strony, a wpisania w kontekst życia umysłowego - z drugiej („diachronicznej” - „powiedziałem «eksplozję», bo to chyba najlepsze słowo, biorąc pod uwagę moje wcześniejsze doświadczenia”). W związku z tym opisy Dennetta typu ,jak to jest być luterańskim parafianinem słuchającym Bacha w Lipsku w 1720 roku” są jak najbardziej na miejscu, ale z pewnością nie mogą być argumentem za tezą, że qualia są fikcją ${ }^{120}$.

Dodajmy jeszcze, że stosunek między ja a polem czuciowym, który został tylko w przybliżeniu opisany niejasnymi metaforami, sprawiał fenomenologom kłopoty. Np. Edyta Stein z jednej strony podkreśla, że wrażenie „nie wypływa z czystego «ja»" i „nigdy nie przyjmuje postaci «cogito»"121, podczas gdy kilka

117 W każdym razie ani „klasyczna”, ani „ucieleśniona” fenomenologia (jeśli w ogóle dokonywać takiego podziału) nie popiera w tym względzie Hume’a. James Baillie i Józef Bremer za Oliverem Sacksem sugerują, że gdyby Hume miał rację, podmiot cierpiałby na coś podobnego do zespołu Korsakowa [!] (zob. J. Baillie, Problems in Personal Identity, Paragon House, New York 1993, s. 107 i nn.; J. Bremer, Osoba..., dz. cyt., s. 181, przyp. 11.

118 S. Gallagher, D. Zahavi, The Phenomenological Mind..., dz. cyt., s. 118.

119 Piszę tak ostrożnie, by nie przesądzać o prawdziwości tej teorii. Zob. M. Rosiak, Realizm i czas, w: Świadomość, świat, wartości, red. D. Leszczyński, M. Rosiak, Oficyna Naukowa PFF, Wrocław 2013, s. 383 i nn., a zwłaszcza przyp. 42; tenże, Czym jest rozciagłość, „Lectiones \& Acroases Philosophicae" 2015, t. 8, nr 2, s. 38 i nn., 44.

120 Por. D. Dennett, Consciousness Explained, Little, Brown and Co., Boston-Toronto-London 1991, s. 386-388. W planowanej rozprawie dodam także swoje trzy grosze do krytycznych analiz tej pracy.

121 E. Stein, On the Problem..., dz. cyt., s. 42. 
stron dalej twierdzi, że „wrażenia są realnymi składnikami świadomości i jako takie przynależą «ja»" i że „zmysłowe uczucia [...] wypływają z mojego «ja»"122. Można przypuszczać, że nieprzypadkowo $\mathrm{w}$ tych kolejnych miejscach nie ma mowy o „czystości” tego ja, ale chodzi też, jak sądzę, o to, że wrażenia czy (u) czucia, jako konstytuujące sferę świadomości, nie mogą być bez ja, skoro świadomość bez ja jest nie do pomyślenia ${ }^{123}$. Nie ma natomiast sensu upodabnianie wrażenia do percepcji poprzez wiązanie wrażenia $\mathrm{z}$ podmiotem $\mathrm{z}$ jednej strony a przedmiotem $z$ drugiej na sposób: „odnoszę wrażenie, że $p$ ” - zwrot ten ma bowiem sens czysto metaforyczny: „odnoszę wrażenie, że tam stoi drzewo” znaczy tyle co „wydaje mi się, że tam stoi drzewo”, względnie „tamto wygląda mi na drzewo”. Albo, bardziej bezpośrednio: „hm, takie wrażenia wzrokowe wytwarzać może drzewo"124. Przy czym ten ostatni zwrot wyraża spontanicznie (naturalnie, por. „nastawienie naturalne”) żywione przekonanie realistyczne.

Istnieje jednak jeszcze inna interpretacja stanowiska fenomenologii ucieleśnionej w kwestii tradycyjnego problemu psychofizycznego. Można potraktować przytoczone wypowiedzi ich przedstawicieli za niefortunne, a uwydatnić taką na przykład: „pojęcie ucieleśnienia, pojęcie ucieleśnionego umysłu lub «uumysłowionego» (minded) ciała, ma za zadanie zastąpić tradycyjne pojęcia umysłu i ciała, które to pojęcia są derywacjami i abstrakcjami [w stosunku do tych poprzednich]"125. Evan Thompson ${ }^{126}$ i Robert Hanna interpretują to następująco: problem psychofizyczny ma, jak rzekomo pokazuje współczesna fenomenologia

122 Tamże, s. 48 i nn.

123 Na marginesie: anonimowy recenzent wskazał, że świadomość bez ja pomyślał Sartre w latach 30. Owszem, w tym sensie „pomyślało” ją sobie wielu: Hume, Lichtenberg, Nietzsche, Parfit, Metzinger, nie mówiąc o samym Husserlu (w Badaniu Piątym) - pytanie tylko, czy nie ulegli nieporozumieniu (pozytywną odpowiedź na nie uzasadnił moim zdaniem Zahavi w Subjectivity and Selfhood..., dz. cyt., s. 33-36, 99-130).

124 Ta ostatnia parafraza może wydawać się (nomen omen) nietrafna, jeśli abstrahujemy od (domniemanego tu jedynie) kontekstu sytuacyjnego.

125 S. Gallagher, D. Zahavi, The Phenomenological Mind..., dz. cyt., s. 135. Także w Subjectivity and Selfhood... Zahavi podkreśla tuż po tezie „jestem ciałem”, że chodzi o Leib, podczas gdy Koerper to „abstrakcja” (s. 205 i nn.).

126 Wraz z Franciskiem Varelą i Emily Rosch współautor The Embodied Mind (MIT Press, Cambridge, MA 1991), uważaną za pracę otwierającą „ucieleśnioną” odmianę zarówno współczesnej fenomenologii jak i kognitywistyki. 
i kognitywistyka, „proste” rozwiązanie - własności „świadomościowe”, czy też „przeżyciowe” (albo phenomenal, w żargonie współczesnej filozofii umysłu), i fizyczne („,konstytuujące” Koerper) to nieidentyczne ze sobą, ale konieczne, aspekty Leib ${ }^{127}$. Chodzi więc o znaną skądinąd tzw. teorię podwójnego aspektu, tyle że nie mamy tu „neutralnego" czy „protofenomenalnego" albo wręcz „nieznanego" $X$ będącego podmiotem tych aspektów, ale znany $\mathrm{z}$ fenomenologii Leib. Autorzy są świadomi tego, że nieidentyczność (w sensie negacji logicznej identyczności ${ }^{128}$ ) to jedno; drugie to pozytywna charakterystyka relacji między wspomnianymi „aspektami”. Hanna i Thompson piszą o „nie-analitycznej konieczności” i tak ją definiują: zdanie $P$ jest nie-analitycznie konieczne wtedy i tylko wtedy, gdy $P$ jest prawdziwe w każdym logicznie możliwym świecie niesprzecznym z „metafizyką świata realnego" (przy czym światy te muszą być też fizycznie możliwe), natomiast poza wyróżnioną klasą światów weryfikujących $P$ zdanie to nie przyjmuje żadnej wartości logicznej ${ }^{129}$. Pomijając już pytanie, co należy rozumieć przez logiczną możliwośćc ${ }^{130}$ i o jakiej to metafizyce mowa, z pewnością nie ma to większego związku z fenomenologią „ucieleśnioną” niż np. z propozycją Chalmersa, którego autorzy zresztą błędnie interpretują (np. jako rzekomo różniącego się w kwestii zombi ${ }^{131}$ ). W eseju pt. Świadomość $i$ jej miejsce $w$ naturze australijski filozof wyraźnie skłania się ku neorussellizmowi, który opisuje czasem podobnie jak autorzy, tj. jako teorię podwójnego aspektu ${ }^{132}$, ale czasem też interpretuje jako wariant teorii tożsamości psychofizycznej właśnie ${ }^{133}$ ! Zakładając tzw. strukturalizm fizyczny (musimy odłożyć dyskusję nad argumentami za tym stanowiskiem) $)^{134}$, niektórym może nasunąć się możliwość, że przeżyciowy cha-

127 Zob. R. Hanna, E. Thompson, The Mind-Body-Body Problem, „Theoria et Historia Scientiarium” 2003, Vol. 7, No. 1, s. 25-44.

128 Identyczność logiczna spełnia określone aksjomaty: jest relacją zwrotną i implikuje nieodróżnialność (co z kolei pociąga m.in. symetryczność i przechodniość), zob. np. P. Garbacz, Logika i artefakty, Wyd. KUL, Lublin 2006, s. 43 (nb., formalizm jest opisany na s. 16 i nn.).

129 R. Hanna, E. Thompson, The Mind..., dz. cyt., s. 31.

130 Por. T. Kąkol, Monadologia Leibniza dziś, „Studia Philosophica Wratislaviensia” 2018, t. 13, nr 1, s. 47 , przyp. 36.

131 R. Hanna, E. Thompson, The Mind..., dz. cyt., s. 38-40.

132 Por. D. Chalmers, Świadomość..., dz. cyt., s. 484, 487.

133 Stąd nazywa go często „monizmem” (pewnego typu). Tamże, s. 482, 484 i nn.

134 Zob. np. J. Foster, The Immaterial Self. A Defence of the Cartesian Dualist Conception of Mind, Routledge, London and New York 1991, s. 121-125; W. V. O. Quine, Rzeczy i ich miejsce w teoriach, tł. T. Szubka, w: Metafizyka w filozofii analitycznej, red. T. Szubka, TN KUL, Lublin 1995, s. 48; D. Chalmers, Świadomość... w: Analityczna metafizyka..., s. 446, 468 i nn., 482-484. 
rakter jest aspektem fizycznego, i to aspektem fundamentalnym - w tym sensie, że to, co zwykle nazywamy „fizycznym”, jest „zaledwie” formą, strukturą, siecią relacji (przestrzennych, przyczynowych) i dyspozycji (czynnych i biernych), a nie „treścią”, „«co» rzeczy”: tym „czymś” właśnie są qualia ${ }^{135}$. Tak w każdym razie można również interpretować tezę, że Leib jest podstawowy, a Koerper z „fizycznej”, a qualia z „mentalnej” strony - „abstrakcjami”. Czy jednak o to chodzi liderom „fenomenologii ucieleśnionej”? I jaki argument można wysunąć na rzecz tego stanowiska, skoro fenomenologicznie właśnie - jak wyżej staraliśmy się wykazać - sprawa z tożsamością ja i Leib ma się inaczej ${ }^{136}$ ?

Reasumując, starałem się pokazać, że odpowiedź na pytanie „czy w świetle fenomenologii ucieleśnionej teza o tożsamości psychofizycznej jest lepiej uzasadniona?” jest negatywna. Fenomenologia, zgodnie z drugim mottem, słusznie stara się wiernie opisać świadome doświadczenie zamiast przystępować z niesprecyzowanymi intuicjami na temat „świadomości” do zagadnienia redukcji czy braku takowej. Zgodnie jednak z pierwszym mottem, problem psychofizyczny pozostaje tak samo zagadkowy, jak przed opisami powstałymi w obrębie nurtu „fenomenologii ucieleśnionej”: sprawa domniemanej tożsamości psychofizycznej jest i być może długo jeszcze pozostanie otwarta ${ }^{137}$.

Ciekawy argument podaje M. Heller w swoich Elementach mechaniki kwantowej dla filozofów (Copernicus Center Press, Kraków 2014, s. 168-172; przegląd sporu w tenże, Spór o realizm strukturalistyczny, w: tegoż, Filozofia i wszechświat, Universitas, Kraków 2012, s. 197-234).

135 Por. J. Foster, The Immaterial..., dz. cyt., s. 121-125. Choć dla wielu zaliczanie Chalmersa do skłaniających się ku teorii tożsamości psychofizycznej brzmi jak dysonans, sam Chalmers wyraźnie uważa za kwestię terminologiczną, a nie ściśle rzeczową, zaliczanie neorussellizmu do grupy teorii, jak pisze, „materialistycznych” (zob. D. Chalmers, Świadomość..., dz. cyt., s. 484 i nn.).

136 Wracając jeszcze do wspomnianej propozycji Hanny i Thompsona, można jeszcze dodać, że ich utożsamienie Leib z „animal” brzmi jak dysonans, zwłaszcza gdy weźmiemy pod uwagę przywoływanego przez nich Erica Olsona. Zob. R. Hanna, E. Thompson, The Mind..., s. 26 i nn., 32 i nn. i wyżej, przyp. 111.

137 Niektórzy mogą jeszcze wziąć pod uwagę deklarację Gallaghera i Zahaviego, iż „tym, co odkrywamy w fenomenologii... jest umyślne zatarcie różnicy między ontologią a epistemologią i, w konsekwencji, jasne odrzucenie realizmu metafizycznego" (S. Gallagher, D. Zahavi, The Phenomenological Mind..., dz. cyt., s. 126). Jeśli jednak tak ma się rzecz, nie tylko problem psychofizyczny, ale wszelkie metafizyczne zagadnienie jest dla fenomenologii nieporozumieniem! 


\section{Bibliografia}

Baillie J., Problems in Personal Identity, Paragon House, New York 1993.

Baker L. R., The First-Person Perspective: A Test for Naturalism, „American Philosophical Quarterly" 1998, Vol. 35, No. 4, s. 327-348.

Baker L. R., Persons and Bodies. A Constitution View, Cambridge University Press, Cambridge, MA 2000.

Bermudez J. L., Bodily Awareness and Self-Consciousness, w: The Oxford Handbook of The Self, ed. S. Gallagher, Oxford University Press, New York 2011, s. 157-179.

Brentano F., Psychologia z empirycznego punktu widzenia, tł. W. Galewicz, PWN, Warszawa 1999.

Bremer J., Osoba - fikcja czy rzeczywistość? Tożsamość i jedność Ja w świetle badań neurologicznych, Aureus, Kraków 2008.

Campbell J., Personal Identity, w: The Oxford Handbook of The Self, ed. S. Gallagher, Oxford University Press, New York 2011, s. 339-351.

Cappelen H., Dever J., The Inessential Indexical. On the Philosophical Insignificance of Perspective and the First Person, Oxford University Press, Oxford 2013.

Chalmers D., Świadomość i jej miejsce w naturze, tł. R. Poczobut, T. Ciecierski, w: Analityczna metafizyka umysłu. Najnowsze kontrowersje, red. M. Miłkowski, R. Poczobut, Wyd. IFiS PAN, Warszawa 2008, s. 442-494.

Chisholm R., The First Person. An Essay on Reference and Intentionality, University of Minneapolis Press, Minneapolis 1981.

Chmielecki A., Między mózgiem a świadomością. Próba rozwiązania problemu psychofizycznego, Wyd. IFiS PAN, Warszawa 2001.

Chrudzimski A., Teoria intencjonalności Rodericka Chisholma, „Kwartalnik Filozoficzny" 2009, t. 37, nr 3, s. 75-87.

Clark A., Chalmers D., Umysł rozszerzony, tł. M. Miłkowski, w: Analityczna metafizyka umysłu. Najnowsze kontrowersje, red. M. Miłkowski, R. Poczobut, Wyd. IFiS PAN, Warszawa 2008, s. 342-357.

Cole J., Agency with Impairments in Movement, w: Handbook of Phenomenology and Cognitive Science, eds. S. Gallagher, D. Schmicking, Springer, DordrechtNew York-Heidelberg-London 2010, s. 655-670. 
Damasio A., Tajemnica świadomości. Ciało i emocje współtworza świadomość, tł. M. Karpiński, Rebis, Poznań 2000.

Dennett D., Consciousness Explained, Little, Brown and Co., Boston-TorontoLondon 1991.

Engel P., Czy naturalistyczna teoria umysłu eliminuje subiektywność?, tł. J. Margański, w: Filozofia podmiotu, red. J. Górnicka-Kalinowska, Aletheia, Warszawa 2001, s. 243-259.

Foster J., The Immaterial Self. A Defence of the Cartesian Dualist Conception of Mind, Routledge, London and New York 1991.

Fuchs T., Phenomenology and Psychopathology, w: Handbook of Phenomenology and Cognitive Science, eds. S. Gallagher, D. Schmicking, Springer, DordrechtNew York-Heidelberg-London 2010, s. 547-573.

Gallagher S., Zahavi D., The Phenomenological Mind. An Introduction to Philosophy of Mind and Cognitive Science, Routledge, London-New York 2008 (polski przekład: Fenomenologiczny umyst, tł. M. Pokropski, PWN, Warszawa 2015).

Garbacz P., Logika i artefakty, Wyd. KUL, Lublin 2006.

Gołosz J., Upływ czasu i ontologia, Wyd. UJ, Kraków 2011.

Haldane J., Teoria identyczności umyst-świat a wyzwanie antyrealizmu, tł. S. Judycki, T. Szubka, w: Filozofia brytyjska u schyłku XX wieku, red. P. Gutowski, T. Szubka, TN KUL, Lublin 1998, s. 117-154.

Hanna R., Thompson E., The Mind-Body-Body Problem, „Theoria et Historia Scientiarium" 2003, Vol. 7, No. 1, s. 25-44.

Heller M., Spór o realizm strukturalistyczny, w: tegoż, Filozofia i wszechświat, Universitas, Kraków 2012, s. 197-234.

Heller M., Elementy mechaniki kwantowej dla filozofów, Copernicus Center Press, Kraków 2014.

Husserl E., Wykłady z fenomenologii wewnętrznej świadomości czasu, tł. J. Sidorek, PWN, Warszawa 1989.

Ingarden R., O niebezpieczeństwie petitionis principii $w$ teorii poznania, tł. D. Gierulanka, w: tegoż, U podstaw teorii poznania, PWN, Warszawa 1971, s. 357-381.

Ingarden R., Spór o istnienie świata, t. II, cz. 2, PWN, Warszawa 1987.

Judycki S., Świadomość i pamięć. Uzasadnienie dualizmu antropologicznego, TN KUL, Lublin 2004. 
Kąkol T., Realizm epistemologiczny. Dyskusja z dwoma wybranymi „manifestami antyrealistycznymi” (Goodman, Putnam), „Filo-Sofija” 2014, nr 27, s. 29-41.

Kąkol T., Monadologia Leibniza dziś, „Studia Philosophica Wratislaviensia” 2018, t. 13, nr 1, s. 39-53.

Kąkol T., In Defense of Presentism and an Extratemporal God, w: God, Time, Infinity, ed. M. Szatkowski, de Gruyter, Berlin-Boston 2018, s. 53-60.

Kąkol T., On empathy. E. Stein and R. Ingarden vs cognitive psychology, „Miscellanea Anthropologica et Sociologica" 2019, t. 20, nr 1, s. 36-45.

Kripke S.A., Nazywanie a konieczność, tł. B. Chwedeńczuk, PAX, Warszawa 1988. Legrand D., Myself with No Body? Body, Bodily-Consciousness and Self-consciousness, w: Handbook of Phenomenology and Cognitive Science, eds. S. Gallagher, D. Schmicking, Springer, Dordrecht-New York-Heidelberg-London 2010, s. 181-200.

Legrand D., Phenomenological Dimensions of Bodily Self-Consciousness, w: The Oxford Handbook of The Self, ed. S. Gallagher, Oxford University Press, New York 2011, s. 204-227.

Lewis D., Attitudes De Dicto and De Se, w: tegoż, Philosophical Papers, Vol. 1, Oxford University Press, New York-Oxford 1983, s. 133-159.

Lewis D., Redukcja umysłu, tł. M. Iwanicki, w: Analityczna metafizyka umysłu. Najnowsze kontrowersje, red. M. Miłkowski, R. Poczobut, Wyd. IFiS PAN, Warszawa 2008, s. 191-222.

Łagosz M., Realność czasu, Wyd. UWr, Wrocław 2007.

Madell G., The Essence of the Self. In Defense of the Simple View of Personal Identity, Routledge, New York-London 2015

Martin R., Self-Concern. An Experiential Approach to What Matters in Survival, Cambridge University Press, Cambridge, MA 1998.

Meixner U., Classical Dualism Modrernized. A Proposal, w: Dualistic Ontology of the Human Person, red. M. Szatkowski, Philosophia Verlag, Muenchen 2013, s. $15-22$.

Mellor D.H., Filozofia analityczna i jaźń, tł. R. Majeran, w: Filozofia brytyjska u schyłku XX wieku, red. P. Gutowski, T. Szubka, TN KUL, Lublin 1998, s. $415-435$.

Mishara A.L., Autoscopy: Disrupted Self in Neuropsychiatric Disorders and Anomalous Conscious States, w: Handbook of Phenomenology and Cognitive 
Science, eds. S. Gallagher, D. Schmicking, Springer, Dordrecht-New YorkHeidelberg-London 2010, s. 591-634.

Morris D., Empirical and Phenomenological Studies of Embodied Cognition, w: Handbook of Phenomenology and Cognitive Science, eds. S. Gallagher,

D. Schmicking, Springer, Dordrecht-New York-Heidelberg-London 2010, s. 235-252.

Nozick R., Philosophical Explanations, Clarendon Press, Oxford 1981.

Olson E., Why I Have no Hands, „Theoria” 1995, Vol. 61, No. 2, s. 182-197.

Olson E., A Compound of Two Substances, w: Soul, Body and Survival, ed.

C. Corcoran, Cornell University Press, Ithaca and London 2001, s. 73-88.

Olson E., Is There a Bodily Criterion of Personal Identity?, URL: https://www.sheffield.ac.uk/polopoly_fs/1.101671!/file/BodilyCriterion.pdf, dostęp: 22.08.2019. Petit J.-L., A Husserlian, Neurophenomenological Approach to Embodiment, w: Handbook of Phenomenology and Cognitive Science, eds. S. Gallagher, D. Schmicking, Springer, Dordrecht-New York-Heidelberg-London 2010, s. 201-216.

Poczobut R., Rodzaje samoświadomości, „Analiza i Egzystencja” 2008, nr 7, s. 5-31.

Pruss A., One Body, Notre Dame University Press, Notre Dame 2013.

Quine W. V. O., Rzeczy i ich miejsce w teoriach, tł. T. Szubka, w: Metafizyka w filozofii analitycznej, red. T. Szubka, TN KUL, Lublin 1995, s. 31-51.

Rosiak M., Realizm i czas, w: Świadomość, świat, wartości, red. D. Leszczyński, M. Rosiak, Oficyna Naukowa PFF, Wrocław 2013, s. 375-389.

Rosiak M., Czym jest rozciagłość, „Lectiones \& Acroases Philosophicae” 2015, t. 8, nr 2, s. 9-51.

Sider T., Four-dimensionalism: an Ontology of Persistence and Time, Oxford University Press, Oxford 2001.

Smith D.W., The Circle of Acquaintance. Perception, Consciousness, and Empathy, Kluwer, Dordrecht-Boston-London 1989.

Stein E., On the Problem of Empathy, tł. W. Stein, ICS Publications, Washington 1989.

Swinburne R., The Structure of the Soul, w: Persons and Personality. A Contemporary Inquiry, eds. A. Peacocke, G. Gillett, Basil Blackwell, Oxford 1987, s. 33-55.

Traczyk W.Z., Fizjologia człowieka w zarysie, PZWL, Warszawa 1989. 
Tsakiris M., The Sense of Body Ownership, w: The Oxford Handbook of The Self, ed. S. Gallagher, Oxford University Press, New York 2011, s. 180-203.

Zahavi D., Beyond Empathy. Phenomenological Approaches to Intersubjectivity, „Journal of Consciousness Studies” 2001, Vol. 8, No. 5-7, s. 151-167.

Zahavi D., First-person thoughts and embodied self-awareness: Some reflections on the relation between recent analytical philosophy and phenomenology, „Phenomenology and the Cognitive Sciences" 2002, Vol. 1, Issue 1, s. 7-26.

Zahavi D., Subjectivity and Selfhood. Investigating the First-Person Perspective, Bradford Book/MIT Press, Cambridge, MA 2005.

Zahavi D., Unity of Consciousness and the Problem of Self, w: The Oxford Handbook of The Self, ed. S. Gallagher, Oxford University Press, New York 2011, s. 316-335.

Ziemińska R., Samoświadomość i samowiedza z punktu widzenia epistemologii, „Analiza i Egzystencja” 2008, nr 7, s. 33-51.

Żełaniec W., On the Non-Paradoxality of the Veridic, „Fenomenologia” 2014, nr 12, s. 77-85.

„Świat Nauki”, 2008 nr 1(9) [wydanie specjalne].

\section{Streszczenie}

Przedstawiciele tzw. fenomenologii ucieleśnionej sprawiają wrażenie, że bronią tezy o tożsamości psychofizycznej. Po argumentacji za nieredukowalnością ja wyróżniam fenomenologicznie tzw. pole czuciowe i ciało rozumiane jako Koerper, wskazując, że utożsamienie tych trzech elementów nie jest wystarczająco uzasadnione, przynajmniej na gruncie fenomenologii.

Słowa kluczowe: ciało, fenomenologia, ja, Koerper, Leib, teza o tożsamości psychofizycznej, ucieleśnienie 


\section{Summary}

\section{Embodied Phenomenology and the Psychophysical Identity Thesis}

Phenomenologists inspired by the embodiment approach seem to subscribe to the psychophysical identity thesis. I argue that I (ego) cannot be eliminated and I differentiate phenomenologically between the sensory field and the body understood as a Koerper holding that the identification of those three items as "in fact one and the same" is not sufficiently warranted, at least on phenomenological grounds.

Key words: body, embodiment, I, Koerper, Leib, phenomenology, the psychophysical identity thesis 